PNNL-11724

UC-630

\title{
Value Tradeoffs for the Hanford Tank Waste Remediation System (TWRS) Program
}

\author{
R. L. Keeney ${ }^{(a)}$ \\ D. von Winterfeldt ${ }^{(\mathrm{a})}$
}

September 1997

Work prepared for

Pacific Northwest National Laboratory

by Decision Insights, Inc.

under U.S. Department of Energy

Contract DE-AC06-76RLO 1830

Pacific Northwest National Laboratory

Richland, Washington 99352

(a) Decision Insights, Inc.

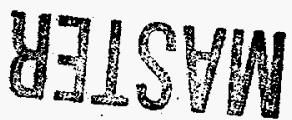

2062 Business Center Drive, Suite 110

Irvine, CA 92621 


\section{DISCLAIMER}

This report was prepared as an account of work sponsored by an agency of the United States Government. Neither the United States Government nor any agency thereof, nor any of their employees, make any warranty, express or implied, or assumes any legal liability or responsibitity for the accuracy, completeness, or usefulness of any information, apparatus, product, or process disclosed, or represents that its use would not infringe privately owned rights. Reference herein to any specific commercial product, process, or service by trade name, trademark, manufacturer, or otherwise does not necessarily constitute or imply its endorsement, recommendation, or favoring by the United States Government or any agency thereof. The views and opinions of authors expressed herein do not necessarily state or reflect those of the United States Government or any agency thereof. 


\section{DISCLAIMER}

Portions of this document may be illegible electronic image products. Images are produced from the best available original document. 


\section{Summary}

The Tank Waste Remediation System (TWRS) program at the Hanford Site of the Department of Energy has adopted a logical approach to making decisions that uses decision analysis to structure and analyze decision alternatives and public values to evaluate them (Robershotte, et al., 1995). This report is the third in a series to support this effort. The first (Armacost et al., 1994) identified a set of objectives (called "ends objectives") that characterize the ultimate goals and desires of Hanford decision makers and stakeholders. The second report (Keeney and von Winterfeldt, 1996) developed operational measures for these ends objectives (called "ends measures") and it also developed a set of performance objectives and associated performance measures that are more directly related to how well decision alternatives in the TWRS program perform to achieve the ends objectives.

The present report describes the development of quantitative value tradeoffs for both the ends measures and the performance measures. First, five national value experts were interviewed to obtain value tradeoffs for units of the ends measures identified in Keeney and von Winterfeldt (1996). The results of this assessment are shown in Table S1. Second, the implied value tradeoffs for the units of the performance measures were calculated from the value tradeoffs for units of the ends measures provided by the national experts. When calculating the value tradeoffs for the units of the performance measures, very simple quantitative relationships between ends and performance measures were assumed. The results of this calculation are shown in Table S2.

The results of this report shown in Tables S1 and S2 should be considered preliminary and largely illustrative of the principles for developing value tradeoffs. The report lists several important caveats and recommendations for how future work can improve on the assessment of value tradeoffs. 
Table S1: Tradeoffs for Ends Measure Units*

\begin{tabular}{|l|l|r|}
\hline \multicolumn{1}{|c|}{ Ends Measure } & \multicolumn{1}{|c|}{ Ends Measure Unit } & $\begin{array}{r}\text { Tradeoff per Unit } \\
\text { of Ends Measure }\end{array}$ \\
& & \\
Years of worker life lost & One Year & $\mathbf{\$ 1 0 0 , 0 0 0}$ \\
Years of worker sickness/injury & One Year & $\mathbf{\$ 2 0 , 0 0 0}$ \\
Years of public life lost & One Year & $\mathbf{\$ 2 5 0 , 0 0 0}$ \\
Years of public sickness/injury & One Year & $\mathbf{\$ 5 0 , 0 0 0}$ \\
Discharges into the Columbia River & One Major Discharge & $\mathbf{\$ 5 , 0 0 0 , 0 0 0}$ \\
Restricted acres - groundwater & One Acre & $\mathbf{\$ 1 , 0 0 0}$ \\
Restricted acres - perm. waste disposal & One Acre & $\mathbf{\$ 5 , 0 0 0}$ \\
Workers forced to leave the area & One Worker & $\mathbf{\$ 2 0 , 0 0 0}$ \\
New (non-Hanford) job created & One Job & $\mathbf{\$ 2 5 , 0 0 0}$ \\
Restricted acres - Native American use & One Acre & $\mathbf{\$ 5 , 0 0 0}$ \\
Disturbed religious/archeological sites & One Site & $\mathbf{\$ 1 , 0 0 0 , 0 0 0}$ \\
Compliance violation scale & One TPA Milestone Violation & $\mathbf{\$ 2 , 0 0 0 , 0 0 0}$ \\
Technology innovation scale & One technology with 100m benefits & $\mathbf{\$ 7 , 0 0 0 , 0 0 0}$ \\
Governmental Cost & \$1 Million & $\mathbf{\$ 1 , 0 0 0 , 0 0 0}$ \\
& & \\
\hline
\end{tabular}

* Tradeoffs are rounded geometric averages of tradeoff elicited individually from five national experts

Table S1: Tradeoffs for Performance Measure Units**

\begin{tabular}{|l|l|r|}
\hline Performance Measure & \multicolumn{1}{|c|}{ Performance Measure Unit } & $\begin{array}{r}\text { Tradeoff per Unit } \\
\text { of Performance } \\
\text { Measure }\end{array}$ \\
\hline Worker Exposure, Normal Operations & 1,000 person-rems & $\mathbf{\$ 3 , 6 0 0 , 0 0 0}$ \\
Worker Exposure, Accidents & 1,000 person-rems & $\mathbf{\$ 5 , 1 0 0 , 0 0 0}$ \\
Public Exposure, Accidents & 1,000 person-rems & $\mathbf{\$ 1 2 , 6 0 0 , 0 0 0}$ \\
Amount of HLW Shipped Off-Site & 1,000 cubic meters & $\mathbf{\$ 3 7 , 7 7 5 , 5 0 0}$ \\
Time to Interim Stabilization & One Year Exceeding TPA Milestone & $\mathbf{\$ 1 , 0 0 0 , 0 0 0}$ \\
Time to Closure of Tanks & One Year Exceeding TPA Milestone & $\mathbf{\$ 4 0 0 , 0 0 0}$ \\
Low Level Waste Left on Site & 1,000 cubic meters & $\mathbf{\$ 7 , 6 2 0 , 0 0 0}$ \\
Total Life Cycle Cost & \$1 million & $\mathbf{\$ 6 5 0 , 0 0 0}$ \\
\hline
\end{tabular}

** Tradeoffs were calculated using the tradeoffs in Table S1 and simple models relating performance measures to ends measures. 


\section{Contents}

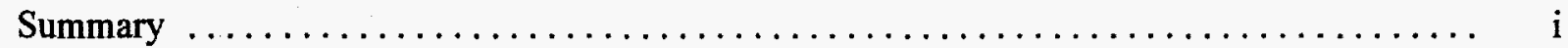

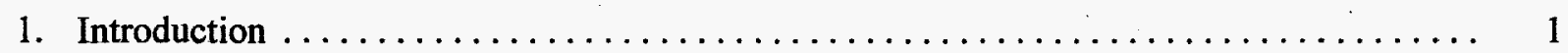

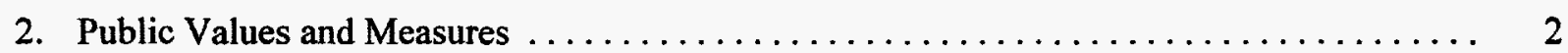

3. Development of Value Tradeoffs for Ends Measures $\ldots \ldots \ldots \ldots \ldots \ldots \ldots \ldots \ldots \ldots .8$

4. Development of Value Tradeoffs for Performance Measures $\ldots \ldots \ldots \ldots \ldots \ldots \ldots \ldots$

5. Uses and Limitations of the Value Tradeoffs $\ldots \ldots \ldots \ldots \ldots \ldots \ldots \ldots \ldots \ldots \ldots \ldots$

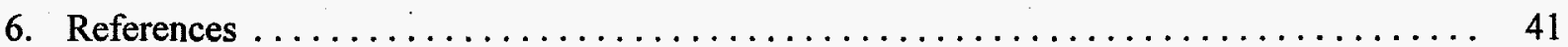




\section{Figures}

1. Relationships Between Performance Measures and Ends Measures

\section{Tables}

S1 Tradeoffs for Ends Measure Units $\ldots \ldots \ldots \ldots \ldots \ldots \ldots \ldots \ldots \ldots \ldots \ldots \ldots \ldots \ldots \ldots \ldots$

S1 Tradeoffs for Performance Measure Units $\ldots \ldots \ldots \ldots \ldots \ldots \ldots \ldots \ldots \ldots \ldots$ ii

1 Ends Objectives and Measures for TWRS Decisions $\ldots \ldots \ldots \ldots \ldots \ldots \ldots \ldots \ldots$

2 Results of Preliminary Value Elicitation with Expert A $\ldots \ldots \ldots \ldots \ldots \ldots \ldots \ldots \ldots$

3 Results of Preliminary Value Elicitation with Expert B $\ldots \ldots \ldots \ldots \ldots \ldots \ldots \ldots$

4 Results of Preliminary Value Elicitation with Expert $\mathrm{C} \ldots \ldots \ldots \ldots \ldots \ldots \ldots \ldots$

5 Results of Preliminary Value Elicitation with Expert $\mathrm{D} \ldots \ldots \ldots \ldots \ldots \ldots \ldots \ldots$

6 Results of Preliminary Value Elicitation with Expert E $\ldots \ldots \ldots \ldots \ldots \ldots \ldots \ldots \ldots \ldots$

7 Summary of Value Tradeoffs for Units of Ends Measures $\ldots \ldots \ldots \ldots \ldots \ldots \ldots \ldots$

8 Matching Ends Measures and Performance Measures $\ldots \ldots \ldots \ldots \ldots \ldots \ldots \ldots \ldots$

9 Matching Ends Measures and Performance Measures $\ldots \ldots \ldots \ldots \ldots \ldots \ldots \ldots$

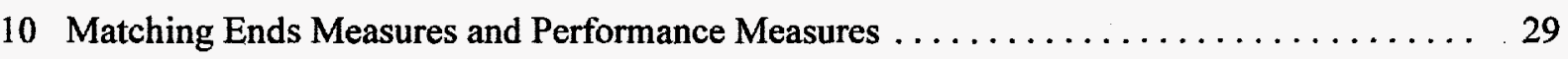

11 Matching Ends Measures and Performance Measures $\ldots \ldots \ldots \ldots \ldots \ldots \ldots \ldots \ldots$

12 Matching Ends Measures and Performance Measures $\ldots \ldots \ldots \ldots \ldots \ldots \ldots \ldots \ldots$

13 Matching Ends Measures and Performance Measures $\ldots \ldots \ldots \ldots \ldots \ldots \ldots \ldots \ldots$

14 Matching Ends Measures and Performance Measures $\ldots \ldots \ldots \ldots \ldots \ldots \ldots \ldots \ldots$

15 Matching Ends Measures and Performance Measures $\ldots \ldots \ldots \ldots \ldots \ldots \ldots \ldots \ldots \ldots$

16 Summary of Tradeoffs for Performance Measure Units $\ldots \ldots \ldots \ldots \ldots \ldots \ldots \ldots \ldots$ 


\section{Introduction}

The Tank Waste Remediation System (TWRS) program has adopted a logical approach to making decisions that uses decision analysis to structure and analyze decision alternatives and public values to evaluate them. To incorporate public values into TWRS decision making, managers need to know how the performance of decision alternatives can be measured to reflect these values, and how to make tradeoffs, if these values are conflicting. In the past, each new decision problem required development of a new set of values and measures and assessment of a new set of tradeoffs specifically tailored to this problem.

Given the similarity between TWRS decision problems, this "re-invention" of public values is not very practical. Therefore, the TWRS program initiated an effort to develop a consistent set of public values; associated measures, and value tradeoffs that could be used as a starting point for an analysis of most TWRS decision problems.

This report is the third in a series describing the results of this effort. The first report (Armacost, von Winterfeldt, Creighton, and Robershotte, 1994) assembled a large list of public value statements from existing reports and it provided some structure to this value list. Most importantly, this report identified a set of "ends" values, that characterize the expressed ultimate goals and desires of Hanford decision makers and stakeholders.

The second report (Keeney and von Winterfeldt, 1996) developed operational measures for these ends objectives. Realizing that it is often hard to actually provide estimates on these measures, this report also provided a set of "performance measures" that more directly relate how well a decision alternative in the TWRS program achieves its objectives. To bridge the gap between performance measures and ends measure, the report also drew qualitative relationships between the two types of measures.

The present report describes the development of quantitative value tradeoffs for both the ends measures and the performance measures. First, five national "value" experts were interviewed to obtain value tradeoffs for units of the ends measures identified in Keeney 
and von Winterfeldt (1996). Second, the implied value tradeoffs for the units of the performance measures were calculated from the value tradeoffs for ends measures provided by the national experts. When calculating the value tradeoffs for units of the performance measures, simple quantitative relationships between ends and performance measures were assumed.

This report is organized as follows. In the Section 2, the ends and performance measures and their qualitative relationships are briefly reviewed, following Armacost et al. (1994) and Keeney and von Winterfeldt (1996). Section 3 describes the process and results of interviews with five national value experts to develop value tradeoffs for units of the ends measures. Section 4 describes the logic and results of developing value tradeoffs for the performance measures. Section 5 discusses the uses and limitations of the tradeoffs presented in this report for TWRS decision making.

\section{Public Values and Measures}

The main result of the report by Armacost et al. (1994) was a list of ends objectives that reflected the ultimate concerns of decision makers, the public, and specific stakeholders with Hanford clean-up. These ends objectives are:

- Protect public/worker health and safety

- Protect the Columbia River

- Protect the environment

- Enable future use options to occur

- Capture economic development locally

- Protect rights of American Indians

- Ensure compliance

- Enhance technology development

- Reduce cost 
Keeney and von Winterfeldt (1996) developed a list of measures that operationalize the meaning of these ends objectives. The purpose of these measures is to communicate to TWRS managers and engineers how to practically interpret the fairly general statements of values and concerns in the above list. Table 1 shows the list of ends objectives and the proposed ends measures.

It is not easy to estimate the achievement of a given set of TWRS alternatives on some of these ends measures. For example, it is very difficult to estimate the long term public health effects of leaving low level waste on the Hanford Site. It is much easier to estimate the type and amount of waste left on site, which will be the major cause of potential long term health effects. Similarly, it is quite difficult to estimate the employment impacts of Hanford operations over the next 50 years, but it is much easier to estimate government expenditures at Hanford, which is the contributor to employment. To facilitate the ease of measurement, Keeney and von Winterfeldt proposed the use of a set of "performance measures" which have direct causal relationships to the ends measures, and which are much easier to measure.

The proposed performance measures are:

- Worker exposure, normal operations (in person-rems)

- Worker exposure, accidents (in person-rems)

- Public exposure, accidents (in person-rems)

- Amount of high level waste (HLW) shipped off site (in cubic meters)

- Amount of low level waste (LLW) left on site (in cubic meters)

- Time to interim stabilization (in years)

- Time to closure of tanks (in years)

- Total lifecycle cost (in 1996 dollars)

The performance measures are causally related to the ends measures. Figure 1 shows these relationships in a qualitative influence diagram. To interpret the figure, consider a 


\section{Table 1: ENDS OBJECTIVES AND MEASURES FOR TWRS DECISIONS}

\section{ENDS OBJECTIVES}

Protect public/worker health and safety

Protect the Columbia River

Protect the environment

Enable future use options

Capture economic development locally

Protect rights of the Native Americans

\section{Ensure compliance}

Enhance technology development

Reduce cost

\section{ENDS MEASURES}

Years of worker-life lost

Years of worker sickness or injury serious enough to miss work Years of public-life lost

Years of public sickness or injury serious enough to miss work

Number of incidents at which a discharge into the Columbia River exceeds clean water standards

Acres of Hanford restricted because of groundwater contamination

Acres of Hanford permanently allocated for waste disposal

Number of workers forced to leave area

Number of new (non Hanford cleanup) jobs created

Acres of Hanford not available for Native American use Number of disturbed and/or inaccessible religious or archaeological sites

Compliance scale

Technology innovation scale

Net cost of clean up to the government (discounted dollars) 


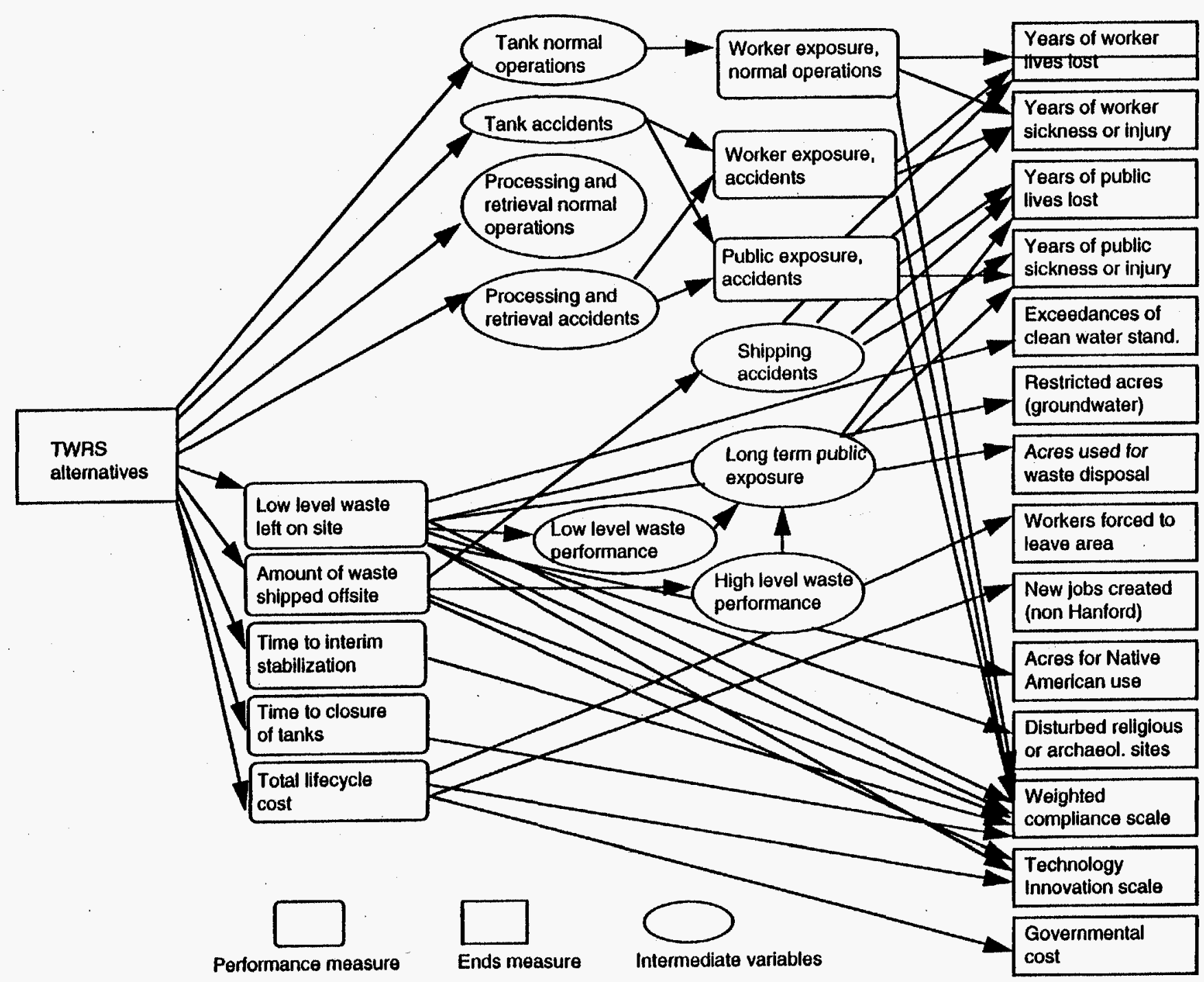

Figure 1: Relationships Between Performance Measures and Ends Measures 
TWRS alternative that produces 350,000 cubic meters of LLW that are left on site. This low level waste may have possible impacts on the water quality of the Columbia River, expressed as the ends measure "Exceedances of clean water standards". It may also have impacts on the groundwater, expressed as the ends measure "Restricted acres for groundwater use." The LLW may also have implications on public health, through a path of LLW performance, long term public exposure, ending in the ends measures "Years of public lives lost" and "Years of public injury or illnesses". Since the LLW disposal takes land, it will affect the ends measure "Acres available for Native American use" and possibly on "Disturbed religious or archaeological Sites". The amount of LLW will have ends measures implications on "Compliance" and "Technology Innovation".

Not every performance measure has such complicated relationships to ends measures. For example, the amount of HLW shipped off site may affect, through high-level waste performance, long term public exposure and thereby the ends measures "Years of public lives lost" and "Years of public injury or illnesses." The amount of HLW also has implications, through shipping accidents, on all four ends measures related to public and worker health and safety. In addition, the amount of $\mathrm{HLW}$ shipped will have some implications on compliance and technology innovation.

Several performance measures have only one major implication on ends measures, e.g. "Time to closure of tanks" which is only related to "Compliance." Note that Figure 1 only draws those relationships from performance measures to the ends measures that are required to determine an alternative's performance on the ends measures. For example, the amount of HLW has significant cost implications as well as the others mentioned above. However, cost is already accounted for by mapping a direct relationship between the TWRS alternative and total lifecycle cost.

As stated above, working with performance measures is typically much easier and more straightforward than working with ends measures. There is, however, one major complication: It is not at all clear, how to assess tradeoffs among the performance measures. For example, what is an appropriate answer to the question: "Should a 
decision maker prefer to eliminate 1000 cubic meters of LLW or to eliminate 1000 rems of worker exposure due to accidents?" Similarly, "Should a decision maker prefer to reduce the time to closure of tanks by 1 year or to eliminate 100 cubic meters of HLW?" The reason why these questions are difficult - perhaps even impossible - to answer directly is because the respondent would have to have a complete mental model of all the causal relationships of how the performance measures affect the ends measures. As are result, it is difficult to develop an appropriate model of the tradeoffs among performance measures when evaluating TWRS alternatives.

Obtaining tradeoffs for the ends measure is, in contrast, a relatively easy task. For example, many people would agree that a year of public life lost is more important than a year of a worker life lost, because members of the public are, in a sense, "innocent bystanders", while workers take the risks knowingly and with some compensation for taking them. Even if people do not agree with this value judgment, they would find ways to reason about it, e.g., by arguing that a life is a life and that it should not matter whether the person is a worker or a member of the public.

Since tradeoffs for ends measures can be obtained more easily than tradeoffs for performance measures, it should be possible to first assess tradeoffs for the ends measures and then calculate back the "implied" tradeoffs for the performance measures. For example, assume that one values the loss of one year of a worker life to be equivalent to the loss of $\$ 100,000$. Further, assume that 1000 rems statistically cause the loss of a worker life, which, on average means losing 30 years of expected life. Then the 1000 rems should be valued the same as the loss of $\$ 3,000,000$.

It is important to point out that for the purpose of these backward calculations of tradeoffs, one does not need to know the complete functional relationship between the performance measure and the ends measures. Assuming that the relationships are reasonably linear, it is sufficient to know the relationships at two points. Since zero impact on the performance measure means zero impact on the ends measures for all relationships, it is sufficient to find one point, e.g. how one unit on the performance 
measures translates into one unit on the ends measures. When a single performance measure affects many ends measures, it is usually reasonable to simply add the units across the ends measures.

To determine the tradeoffs for performance measures, four steps are therefore required:

1. Determine unit tradeoffs for the ends measures.

2. Determine how many units of the ends measure results from one unit of the performance measure.

3. Multiply this number of units of the ends measure times the unit tradeoff of the ends measure to determine the contribution to the unit tradeoff of the performance measure to that ends measure.

4. When the performance measure leads to consequences in terms of several ends measures, repeat steps $1-3$ and add up the resulting contributions to obtain the unit tradeoff for the performance measure.

Step 1 is a an important result in and by itself. The process of developing these unit tradeoffs for ends measures and the results are described in the next section, followed by a description of the calculation of the tradeoffs for the performance measures (steps 2 to 4 ).

\section{Development of Value Tradeoffs for Ends Measures}

Value tradeoffs for the fourteen ends measures were obtained in five separate interviews with nationally known experts who have thought hard about appropriate value tradeoffs for public decisions and who also have substantial knowledge about risk and environmental issues. The experts were: 
David Bell, Professor, Harvard Business School

John Garrick, President, Pickard, Lowe and Garrick

Warner North, Senior Vice-President, Decision Focus, Inc.

Howard Raiffa, Professor Emeritus, Harvard Business School

Christopher Whipple, Vice President, ICF Clement Associates

Three of these experts have been involved in work at Hanford. All of them have worked on major National Research Council Committees, and three have been members of the Council's Board on Nuclear Waste Management. While it is certainly desirable to increase the number of experts in this exercise as well as to involve non-experts, obtaining value tradeoffs from these nationally known experts is a reasonable starting point for developing a set of baseline value tradeoffs.

The interviews were conducted by the authors, both separately (three interviews) and jointly (two interviews). The interviews typically lasted between one and one-half hours and two hours. The interviewer first introduced the purpose of the tradeoff elicitation and showed the expert the list of ends measures for which tradeoffs were to be assigned. The interviewer also explained that the result of the assessment should be a set of tradeoffs expressed as equivalent dollar costs per unit of the ends measure. While this was always the end result of the interview, the actual tradeoff questions did not always directly ask for an answer to the question "How much money should society spend for a reduction of one unit of the ends measure?" Instead, in many cases, tradeoffs between non-monetary ends measures were established and the results were then used to calculate the implied unit cost tradeoffs.

To provide the expert with a perspective when making tradeoffs, the interviewer emphasized that these tradeoffs should be prescriptive, i.e., they should reflect how the expert thought society should allocate its resources, not how specific organizations do allocate resources. One expert provided answers in terms of "politically appropriate" tradeoffs which accounts for some differences between the tradeoffs that he would have considered more reasonable for society as a whole. In other cases, specific ends values, 
especially those related to compliance and standards evoked spirited discussions about the appropriate tradeoffs. In all cases, these discussions were incorporated into the interview summary, so that both the ambivalence of the experts, the ranges of answers and the reasoning for different answers could be recorded. In addition, the interviewer asked for and recorded information that the expert would find useful in providing more informed answers to the tradeoff questions.

It is important to note that the intent of these interviews was to obtain a first-cut idea of appropriate value tradeoffs and suggestions to improve them. Hence, the discussion did not include an in-depth probing for the basis of expressed values nor did it include a complete set of consistency checks. The probing was more about what information would be useful to guide the values assigned and it involved a few selected consistency checks.

Tables 2 through 6 provide the results of the individual interviews. To illustrate the results, consider Table 2 with the tradeoffs of expert A. This expert felt more comfortable with assessing value tradeoffs for years of worker sickness than for years of life loss. He assumed that all costs of sickness were paid for by insurance and that the worker would continue to draw a salary from the employer during the leave. He then directly assigned a value tradeoff of $\$ 10,000$ per year of worker sickness, based on his assessment of a fair compensation for a worker for one year of illness. The expert also felt that one year of worker life lost was 10 times more important than one year of worker sickness. This led him to assign a value of $\$ 100,000$ to one year of worker life lost. The expert also considered one year of public life lost or one year of public sickness to be somewhat more important than those of workers. By assigning a $30 \%$ higher value, he arrived at the corresponding tradeoffs of $\$ 130,000$ per year of public life lost and $\$ 13,000$ per year of public illness or injury.

Many of the other value tradeoffs of this expert are explained in column 3 of Table 2. A few of these tradeoffs need more explanation. The expert assigned a high value tradeoff 


\begin{tabular}{|c|c|c|c|}
\hline $\begin{array}{l}\text { 1. Unit of Ends } \\
\text { Measure }\end{array}$ & $\begin{array}{l}\text { 2. Value } \\
\text { Tradeoff }\end{array}$ & $\begin{array}{l}\text { 3. How Value Tradeoff was } \\
\text { Determined }\end{array}$ & 4. Useful Information \\
\hline $\begin{array}{l}X_{1}=\text { year of } \\
\text { worker-life lost }\end{array}$ & $\$ 100,000$ & $\begin{array}{l}1 \text { year of life lost for worker } \\
\text { equivalent to } 10 \text { years of sickness. }\end{array}$ & $\begin{array}{l}\text { What is the age of workers who } \\
\text { die? }\end{array}$ \\
\hline $\begin{array}{l}X_{2}=\text { year of } \\
\text { worker sickness } \\
\text { or serious injury }\end{array}$ & $\$ 10,000$ & $\begin{array}{l}\text { Direct assessment assuming that } \\
\text { sick workers are financially } \\
\text { compensated by insurance. }\end{array}$ & $\begin{array}{l}\text { Are sick workers compensated? } \\
\text { How and how much? }\end{array}$ \\
\hline $\begin{array}{l}X_{3}=\text { year of } \\
\text { public-life lost }\end{array}$ & $\$ 130,000$ & $\begin{array}{l}\text { A public life-year is weighted } 1.3 \\
\text { times a worker life-year in } \mathrm{X}_{1} \text {. }\end{array}$ & $\begin{array}{l}\text { What is the age of people who } \\
\text { die? }\end{array}$ \\
\hline $\begin{array}{l}X_{4}=\text { year of } \\
\text { public sickness or } \\
\text { serious injury }\end{array}$ & $\$ 13,000$ & $\begin{array}{l}\text { A public year of sickness is } \\
\text { weighted } 1.3 \text { times a worker year } \\
\text { of sickness in } X_{2} \text {. }\end{array}$ & $\begin{array}{l}\text { Are sick members of the public } \\
\text { compensated? How and how } \\
\text { much? }\end{array}$ \\
\hline $\begin{array}{l}\mathrm{X}_{5}=\text { a discharge } \\
\text { into the Columbia } \\
\text { River that exceeds } \\
\text { clean water } \\
\text { standards }\end{array}$ & $\$ 30,000,000$ & $\begin{array}{l}\text { Direct assessment assuming there } \\
\text { are no consequences to human } \\
\text { health, but there are consequences } \\
\text { to fish, agricultural uses of water, } \\
\text { and psychiological impacts that } \\
\text { cause human effects. Checks } \\
\text { indicated this is equivilant to } 300 \\
\text { years of worker life-lost and } 600 \\
\text { acres permanently restricted } \\
\text { because of waste storage. }\end{array}$ & $\begin{array}{l}\text { - A description of the } \\
\text { discharge. } \\
\text { - A description of the full } \\
\text { consequences of the } \\
\text { discharge. }\end{array}$ \\
\hline $\begin{array}{l}\mathrm{X}_{6}=\text { An acre of } \\
\text { Hanford restricted } \\
\text { because of } \\
\text { groundwater } \\
\text { contamination } \\
\end{array}$ & $\$ 50,000$ & $\begin{array}{l}\text { Tradeoff set equal to acre value for } \\
\mathrm{X}_{7}\end{array}$ & \\
\hline $\begin{array}{l}X_{7}=\text { An acre of } \\
\text { Hanford } \\
\text { permanently } \\
\text { allocated for } \\
\text { waste disposal }\end{array}$ & $\$ 50,000$ & $\begin{array}{l}\text { Direct assessment assuming there } \\
\text { would always be at least one acre } \\
\text { for storage. Hence, this value } \\
\text { tradeoff neglected the 'existence of } \\
\text { waste' value of eliminating that } \\
\text { last acre. }\end{array}$ & $\begin{array}{l}\text { The potential uses of the land, } \\
\text { value of their uses, and the } \\
\text { number of individuals interested } \\
\text { in the uses. }\end{array}$ \\
\hline $\begin{array}{l}x_{8}=A \text { worker } \\
\text { forced to leave the } \\
\text { area }\end{array}$ & $\$ 10,000$ & $\begin{array}{l}\text { The assessment assumes that the } \\
\text { move provides an equivalent job. } \\
\text { Value tradeoff is set equal to a year } \\
\text { of worker sickness of } X_{2} \text {. }\end{array}$ & $\begin{array}{l}\text { Describe clearly the scenario that } \\
\text { is meant by a worker forced to } \\
\text { leave the area. }\end{array}$ \\
\hline
\end{tabular}


Table 2, continued

\begin{tabular}{|c|c|c|c|}
\hline $\begin{array}{l}X_{9}=A \text { new (non- } \\
\text { Hanford cleanup) } \\
\text { job created }\end{array}$ & $\$ 8,000$ & $\begin{array}{l}\text { Direct assessment assuming this is } \\
\text { slightly less important than a worker } \\
\text { forced to leave the area in } \mathrm{X}_{8} \text {. }\end{array}$ & $\begin{array}{l}\text { Be specific about the details of } \\
\text { the job created. }\end{array}$ \\
\hline $\begin{array}{l}X_{10}=\text { One acre of } \\
\text { Hanford not } \\
\text { available for } \\
\text { Native American } \\
\text { use }\end{array}$ & $\$ 10,000$ & $\begin{array}{l}\text { Direct assessment assuming this is } \\
\text { an acre not available accounted for } \\
\text { in } \mathrm{X}_{6} \text { or } \mathrm{X}_{7} \text {. The value tradeoff } \\
\text { assumes this acre is of interest to } \\
\text { Native Americans, so the group of } \\
\text { individuals not able to use the acre } \\
\text { in larger than otherwise would be } \\
\text { the case. Assumes acre is not a } \\
\text { special site. The value is much less } \\
\text { than the restriction of an acre } \\
\text { because of groundwater } \\
\text { contamination, as it is on top of that } \\
\text { value. }\end{array}$ & $\begin{array}{l}\text { The Native Americans should } \\
\text { be asked these tradeoffs. } \\
\text { Information about their } \\
\text { reasoning would be useful. } \\
\text { How many areas of Hanford } \\
\text { are of interest to Native } \\
\text { Americans? Why are these of } \\
\text { interest? }\end{array}$ \\
\hline $\begin{array}{l}\mathrm{X}_{11}=\text { One } \\
\text { disturbed or } \\
\text { inaccessible } \\
\text { religious or } \\
\text { archeological site } \\
\text { important to the } \\
\text { Native Americans }\end{array}$ & $\$ 100,000$ & $\begin{array}{l}\text { Direct assessment plus logical check } \\
\text { that the value is equivalent to } 10 \\
\text { acres of } \mathrm{X}_{10} \text {. Assessment assumed } \\
\text { less than } 10 \text { such sites exist and } \\
\text { each is at most a few acres in size. }\end{array}$ & $\begin{array}{l}\text { What are the sites? How many? } \\
\text { What size? Obtain Native } \\
\text { American value judgments on } \\
\text { this. }\end{array}$ \\
\hline $\begin{array}{l}X_{12}=\text { One } \\
\text { violation of the } \\
\text { Clean Water Act }\end{array}$ & $\$ 100,000$ & $\begin{array}{l}\text { Direct assessment based on } \\
\text { importance of showing respect for } \\
\text { the law. This assumed that the } \\
\text { violation was not intended, but that } \\
\text { it would be publicly known that the } \\
\text { violation occurred. }\end{array}$ & $\begin{array}{l}\text { What is the legal liability for a } \\
\text { violation? What consequences } \\
\text { are assumed to result? Are } \\
\text { there prison terms or fines? }\end{array}$ \\
\hline $\begin{array}{l}X_{13}=\$ 1,000 \text { life- } \\
\text { cycle cost }\end{array}$ & $\$ 1,000$ & Simple reasoning & \\
\hline
\end{tabular}


( $\$ 30$ million) to a discharge into the Columbia River, $\mathrm{X}_{11}$, but he was unsure about the nature of the discharge. He made the assumptions that the discharge had no health effects, although there might be some effects on the flora and fauna, and the discharge might create fears and other psychological effects on people. He would assign higher tradeoffs, if the violation had health impacts, if programs would be delayed, fines imposed, etc.

Expert B's tradeoffs and the reasoning behind them are quite straightforward (see Table 3). He assigned large value tradeoff ( $\$ 1$ million) for one disturbed or inaccessible religious or archaeological site important to Native Americans. When making this tradeoff, he assumed that the site was significant, and that it would cost about $\$ 1$ million to avoid impacting the site (e.g., by re-routing a planned road). He also assigned a very large value tradeoff ( $\$ 100$ million) to avoid one compliance violation, which he defined as one violation of a major Tri-Party Agreement (TPA) milestone (notice that this is a somewhat different definition of the unit for this measure than expert A's). His reasoning was that the management of the TWRS program would probably be willing to spend a significant amount of money to avoid such a violation, perhaps as much as $10-25 \%$ of their annual budget. Expert $B$ was one of the two experts (the other one being expert $E$ ), who assigned a tradeoff to technology benefits. He stated that the "spin-off" benefits from technologies are often highly exaggerated, especially for specialized technologies like those involved in Hanford clean-up. He therefore assigned a value of about $10 \%$ of the direct benefits to the benefits of technology transfer and spin offs.

The issue of the proper definition of a unit for performance measure $\mathrm{X}_{5}$ (discharges into the Columbia River exceeding the clean water standard) came up again with expert $C$ (Table 4), who felt that the value tradeoff would depend tremendously on the nature of the discharge. At one extreme, if there were serious consequences, he would assign as much as $\$ 20$ billion to this discharge. If, on the other hand, the discharge was not serious, he would assign a value tradeoff of only $\$ 1$ million. Since the spirit of the performance measure is to capture the latter event (the former being captured in the health measures), the lower tradeoff was carried further into the analysis. 


\begin{tabular}{|c|c|c|c|}
\hline $\begin{array}{l}\text { 1. Unit of Ends } \\
\text { Measure }\end{array}$ & $\begin{array}{l}\text { 2. Value } \\
\text { Tradeoff }\end{array}$ & $\begin{array}{l}\text { 3. How Value Tradeoff was } \\
\text { Determined }\end{array}$ & 4. Useful Information \\
\hline $\begin{array}{l}\mathbf{X}_{1}=\text { year of } \\
\text { worker-life lost }\end{array}$ & $\$ 100,000$ & $\begin{array}{l}\text { Started with } \$ 1 \text { to } \$ 10 \text { million per } \\
\text { worker life, with } 30 \text { remaining } \\
\text { years of average life expectancy, } \\
\text { leaning towards the lower end, } \\
\text { e.g.. \$3 million }\end{array}$ & $\begin{array}{l}\text { What is the implied value of a } \\
\text { worker life for OSHA regulations } \\
\text { of accident risks? }\end{array}$ \\
\hline $\begin{array}{l}X_{2}=\text { year of } \\
\text { worker sickness } \\
\text { or serious injury }\end{array}$ & $\$ 30,000$ & $\begin{array}{l}\text { Considers lost time, lost } \\
\text { productivity and pain and } \\
\text { suffering. About } \$ 3 \mathrm{~K} \text { for one } \\
\text { month. }\end{array}$ & $\begin{array}{l}\text { Statistics for the cost of lost } \\
\text { productivity and for } \\
\text { compensation for pain and } \\
\text { suffering? }\end{array}$ \\
\hline $\begin{array}{l}X_{3}=\text { year of } \\
\text { public-life lost }\end{array}$ & $\$ 300,000$ & $\begin{array}{l}\text { A public life-year is weighted } 3 \\
\text { times a worker life-year in } X_{1} \text {. }\end{array}$ & \\
\hline $\begin{array}{l}X_{4}=\text { year of } \\
\text { public sickness or } \\
\text { serious injury }\end{array}$ & $\$ 90,000$ & $\begin{array}{l}\text { A public year of sickness is } \\
\text { weighted } 3 \text { times a worker year of } \\
\text { sickness in } \mathrm{X}_{2} \text {. }\end{array}$ & \\
\hline $\begin{array}{l}\mathbf{X}_{5}=\text { a discharge } \\
\text { into the Columbia } \\
\text { River that exceeds } \\
\text { clean water } \\
\text { standards }\end{array}$ & $\$ 5,000,000$ & $\begin{array}{l}\text { Direct assessment assuming a } \\
\text { major discharge, but no } \\
\text { consequences to human health. } \\
\text { Includes the precursor and signal } \\
\text { concerns with such an event and } \\
\text { considers actions to remediate. }\end{array}$ & $\begin{array}{l}\text { - cost of remediation } \\
\text { - percentage of } \mathrm{Ci} \text { in spill } \\
\text { relative to site }\end{array}$ \\
\hline $\begin{array}{l}\mathrm{X}_{6}=\text { An acre of } \\
\text { Hanford restricted } \\
\text { because of } \\
\text { groundwater } \\
\text { contamination }\end{array}$ & $\$ 1,000$ & $\begin{array}{l}\text { Only loss of use is drilling and } \\
\text { drinking local groundwater, } \\
\text { otherwise use real estate value. }\end{array}$ & Real estate value \\
\hline $\begin{array}{l}X_{7}=\text { An acre of } \\
\text { Hanford } \\
\text { permanently } \\
\text { allocated for } \\
\text { waste disposal } \\
\end{array}$ & $\$ 20,000$ & $\begin{array}{l}\text { Ten times the value of an acre not } \\
\text { accessible to Native American use, } \\
\text { because of permanent restriction }\end{array}$ & \\
\hline $\begin{array}{l}X_{8}=A \text { worker } \\
\text { forced to leave the } \\
\text { area }\end{array}$ & $\$ 20,000$ & $\begin{array}{l}\text { Compensation for } 6 \text { months of lost } \\
\text { wages and work and replacement } \\
\text { cost. }\end{array}$ & $\begin{array}{l}\text { Replacement cost for an average } \\
\text { Hanford worker. }\end{array}$ \\
\hline
\end{tabular}


Table 3 , continued

\begin{tabular}{|l|c|l|l|}
\hline $\begin{array}{l}\mathbf{X}_{\mathbf{g}}=\text { A new (non- } \\
\text { Hanford cleanup) } \\
\text { job created }\end{array}$ & $\$ 20,000$ & $\begin{array}{l}\text { Assumed to be of same value as } \\
\text { avoiding to force a worker to leave } \\
\text { the area }\end{array}$ & . \\
\hline $\begin{array}{l}\mathbf{X}_{\text {in }}=\text { One acre of } \\
\text { Hanford not } \\
\text { available for } \\
\text { Native American } \\
\text { use }\end{array}$ & $\$ 2,000$ & $\begin{array}{l}\text { Double the value of an acre with } \\
\text { restricted use due to groundwater } \\
\text { contamination, as long as it is just } \\
\text { another acre of land and has no } \\
\text { special significance to the Native } \\
\text { Americans }\end{array}$ & \\
\hline $\begin{array}{l}\mathbf{X}_{11}=\text { One } \\
\text { disturbed or } \\
\text { inacessible } \\
\text { religious or } \\
\text { archeological site } \\
\text { important to the } \\
\text { Native Americans }\end{array}$ & $\$ 1,000,000$ & $\begin{array}{l}\text { Assumes a significant site, based on } \\
\text { avoidance cost. Could be as low as } \\
\$ 100,000 \text { and as high as } \$ 10 \\
\text { million, depending on the } \\
\text { significance of the site }\end{array}$ & How significant is the site? \\
\hline $\begin{array}{l}\mathbf{X}_{12}=\text { One } \\
\text { volation of a } \\
\text { major TPA } \\
\text { milestone }\end{array}$ & $\$ 100,000,000$ & $\begin{array}{l}\text { 25\% of the TWRS budget to avoid } \\
\text { missiing the interim stabilization } \\
\text { milestone. Could be as low as 10 } \\
\text { million and as high as one year's } \\
\text { budget (400 million) }\end{array}$ & How important is the violation? \\
\hline $\begin{array}{l}\mathbf{X}_{13}=\text { One major } \\
\text { new technology } \\
\text { with direct benefits } \\
\text { of } \$ 100 \text { million }\end{array}$ & $\$ 100,000$ & $\begin{array}{l}10 \% \text { of direct value for spin-off } \\
\text { potential, generally low for nuclear } \\
\text { waste technologies }\end{array}$ & What are the technologies? \\
\hline $\begin{array}{l}\mathbf{X}_{14}=\$ 1,000 \text { life- } \\
\text { cycle cost }\end{array}$ & $\$ 1,000$ & Simple reasoning & \\
\hline
\end{tabular}


Table 4. Results of Preliminary Value Elicitation with Expert C

\begin{tabular}{|c|c|c|c|}
\hline $\begin{array}{l}\text { 1. Unit of Ends } \\
\text { Measure }\end{array}$ & $\begin{array}{l}\text { 2. Value } \\
\text { Tradeoff }\end{array}$ & $\begin{array}{l}\text { 3. How Value Tradeoff was } \\
\text { Determined }\end{array}$ & 4. Useful Information \\
\hline $\begin{array}{l}X_{1}=\text { year of } \\
\text { worker-life lost }\end{array}$ & $\$ 200,000$ & $\begin{array}{l}1 \text { year of life lost for public is } 2.5 \\
\text { times as significant as a year of life } \\
\text { lost for worker. The main } \\
\text { difference is the voluntary } \\
\text { acceptance of risk. }\end{array}$ & $\begin{array}{l}\text { What is the age of workers who } \\
\text { die? }\end{array}$ \\
\hline $\begin{array}{l}\mathbf{X}_{2}=\text { year of } \\
\text { worker sickness } \\
\text { or serious injury }\end{array}$ & $\$ 40,000$ & $\begin{array}{l}\text { As above, a public year of } \\
\text { sickness is } 2.5 \text { times as important } \\
\text { as a worker year of sickness. }\end{array}$ & $\begin{array}{l}\text { How and how much are sick } \\
\text { workers compensated? What are } \\
\text { the injuries and sicknesses and } \\
\text { the proportions of each? }\end{array}$ \\
\hline $\begin{array}{l}\mathbf{X}_{3}=\text { year of } \\
\text { public-life lost }\end{array}$ & $\$ 500,000$ & $\begin{array}{l}\text { Direct assessment, somewhat } \\
\text { higher than would be assigned to } n \\
\text { on-nuclear related statistical } \\
\text { fatalities. }\end{array}$ & $\begin{array}{l}\text { What is the age of people who } \\
\text { die? }\end{array}$ \\
\hline $\begin{array}{l}\mathbf{X}_{4}=\text { year of } \\
\text { public sickness or } \\
\text { serious injury }\end{array}$ & $\$ 100,000$ & $\begin{array}{l}\text { Averaged over seriousness of the } \\
\text { sickness or injury; assessed as } \\
20 \% \text { of a year of public life lost }\end{array}$ & $\begin{array}{l}\text { What are the injuries and } \\
\text { sicknesses and the proportion of } \\
\text { each? }\end{array}$ \\
\hline $\begin{array}{l}\mathrm{X}_{5}=\text { a discharge } \\
\text { into the Columbia } \\
\text { River that exceeds } \\
\text { clean water } \\
\text { standards }\end{array}$ & $\begin{array}{c}\$ 20,000,000 \\
\text { (Serious discharge) } \\
\$ 1,000,000 \\
\text { (Not serious) }\end{array}$ & $\begin{array}{l}\text { Value tradeoff is very dependent } \\
\text { on the nature of the discharge. A } \\
\text { serious discharge is where } \\
\text { radionuclides are dischagred that } \\
\text { bioaccumulate in the food chain. } \\
\text { As a result } 1000 \text { statistical fatalities } \\
\text { occur with doses not recognized. } \\
\text { The value tradeoff is } \$ 5 \text { billion for } \\
\text { the } 1000 \text { statistical fatalities (as } \\
\text { they are not counted in } X_{3} \text { ) and } \\
\$ 15 \text { billion for the stigma. } \\
\text { A not serious discharge is } \\
\text { pollutants that readily degrade in a } \\
\text { few hours (i.e., short half-life). } \\
\text { The value tradeoff is } \$ 1 \text { million }\end{array}$ & $\begin{array}{l}\text { Details about the discharge are } \\
\text { needed. What are the } \\
\text { consequences of the discharge on } \\
\text { humans and animals? What are } \\
\text { the subsequent changes in } \\
\text { behavior. }\end{array}$ \\
\hline $\begin{array}{l}X_{6}=\text { An acre of } \\
\text { Hanford restricted } \\
\text { because of } \\
\text { groundwater } \\
\text { contamination }\end{array}$ & $\$ 125$ & $\begin{array}{l}\text { Groundwater contamination } \\
\text { assumed to mean no surface } \\
\text { exposure. Value tradeoff is } 5 \% \text { of } \\
\text { an } \mathrm{X}_{7} \text { acre. }\end{array}$ & $\begin{array}{l}\text { Clarify the restriction of surface } \\
\text { uses due to any groundwater } \\
\text { contamination. }\end{array}$ \\
\hline $\begin{array}{l}X_{7}=\text { An acre of } \\
\text { Hanford } \\
\text { permanently } \\
\text { allocated for } \\
\text { waste disposal }\end{array}$ & $\$ 2,500$ & $\begin{array}{l}\text { Define permanent as for at least } \\
1000 \text { years. Assumes location is } \\
\text { not directly at the Columbia River. } \\
\text { Assumes site chosen is an old } \\
\text { reactor site or a good new site for } \\
\text { disposal. Values at approximately } \\
\$ 1.5 \text { million per square mile. }\end{array}$ & $\begin{array}{l}\text { What is the cost to acquire } \\
\text { National Park land? This would } \\
\text { provide an upper bound. }\end{array}$ \\
\hline $\begin{array}{l}X_{8}=A \text { worker } \\
\text { forced to leave the } \\
\text { area }\end{array}$ & $\$ 40,000$ & $\begin{array}{l}\text { The realities of our economy is } \\
\text { that some people need to move to } \\
\text { find jobs. Assumes } 6 \text { months } \\
\text { without job, but with social } \\
\text { benefits. }\end{array}$ & $\begin{array}{l}\text { How long is the worker forced to } \\
\text { leave the area without a job? }\end{array}$ \\
\hline
\end{tabular}


Table 4, continued

\begin{tabular}{|c|c|c|c|}
\hline $\begin{array}{l}X_{9}=A \text { new (non- } \\
\text { Hanford cleanup) } \\
\text { job created }\end{array}$ & $\$ 20,000$ & $\begin{array}{l}\text { Direct assessment assuming this is } \\
\text { less important than a worker forced } \\
\text { to leave the area in } \mathrm{X}_{8} \text {. Must } \\
\text { consider other federal investments to } \\
\text { create jobs and maintain equity. }\end{array}$ & $\begin{array}{l}\text { Clarify whether jobs created are } \\
\text { permanent. How much does it } \\
\text { cost to create jobs in other fields } \\
\text { and areas? }\end{array}$ \\
\hline $\begin{array}{l}X_{10}=\text { One acre of } \\
\text { Hanford not } \\
\text { available for } \\
\text { Native American } \\
\text { use }\end{array}$ & $\$ 2,500$ & $\begin{array}{l}\text { Direct assessment assuming land not } \\
\text { available permanently and that a } \\
\text { treaty with the tribe is violated by } \\
\text { not returning the land for Native } \\
\text { American use. }\end{array}$ & $\begin{array}{l}\text { Clarify the specific interests and } \\
\text { claims of the Native Americans. }\end{array}$ \\
\hline $\begin{array}{l}X_{11}=\text { One } \\
\text { disturbed or } \\
\text { inaccessible } \\
\text { religious or } \\
\text { archeological site } \\
\text { important to the } \\
\text { Native Americans }\end{array}$ & $\begin{array}{l}\$ 100,000,000 \\
\text { (Currently } \\
\text { undisturbed) } \\
\$ 5,000,000 \\
\text { (Previously } \\
\text { disturbed) }\end{array}$ & $\begin{array}{l}\text { Value tradeoff depends substantially } \\
\text { on the type of disturbance. High } \\
\text { value tradeoff is for a currently } \\
\text { undisturbed, low value tradeoff is } \\
\text { for previously disturbed site. Both } \\
\text { cases are for sites that are of special } \\
\text { significance, not just a location } \\
\text { where ancestors once walked. }\end{array}$ & $\begin{array}{l}\text { What are the sites? How many? } \\
\text { Indicate why each is significant. } \\
\text { Are they undisturbed? }\end{array}$ \\
\hline $\begin{array}{l}\mathrm{X}_{12}=\text { One } \\
\text { violation of a } \\
\text { major compliance } \\
\text { agreement of } \\
\text { regulation }\end{array}$ & $\$ 15,000,000$ & $\begin{array}{l}\text { Assumes a violation of a TPA. The } \\
\text { value of the TPA is because it } \\
\text { preeomotes the maintaining of an } \\
\text { open negotiation process and one } \\
\text { where citizens can participate. } \\
\text { Direct assessment mainly due to the } \\
\text { public participation aspect. }\end{array}$ & $\begin{array}{l}\text { What is the legal liability for a } \\
\text { violation? What consequences } \\
\text { are assumed to result? Are } \\
\text { there prison terms or fines? }\end{array}$ \\
\hline $\begin{array}{l}X_{13}=\$ 1,000 \text { life- } \\
\text { cycle cost }\end{array}$ & $\$ 1,000$ & Simple reasor & . \\
\hline
\end{tabular}


Similar reasoning led this expert to assign a range of value tradeoffs to the religious or archeological site important to Native Americans. At the high end, he considered a value tradeoff of $\$ 100$ million to be appropriate, if the site was currently undisturbed and significant. A site that had been previously desecrated, on the other hand, would have a much lower value tradeoff ( $\$ 5$ million).

Expert D (Table 5) made a distinction between what he felt were appropriate tradeoffs from a prescriptive societal perspective, and what he thought were politically appropriate tradeoffs. Here we report only the latter, noting that in several cases the prescriptive tradeoffs were significantly lower than the politically appropriate ones. His assessment of $\$ 93.75$ for an acre of restricted ground water use was based on an assessment of $\$ 12,000$ per square mile. All other tradeoffs were quite straightforward and are explained in column 3 of Table 5 .

Expert E's tradeoffs are explained in column 3 of Table 6 . He also stated that the spin-off benefits of a major technology should be counted as a percentage of the direct benefits. He assigned $\$ 50,000$ to the spin-off and technology transfer benefit of one major technology with significant direct benefits to Hanford. However, "significant direct benefits" were not further defined in the interview. He also stated that it would be reasonable to assign the technology spin off and transfer benefit to be a percentage of the direct benefits, but did not state any specific percentage. Assuming that significant direct benefits are $\$ 1$ million, the assigned tradeoff of $\$ 50,000$ implies a $5 \%$ transfer and spinoff benefit, or $\$ 5$ million for a technology with $\$ 100$ million direct benefits.

Table 7 summarizes the results of the assessments of value tradeoffs of the five experts. The last column of Table 7 shows the rounded geometric average value tradeoff across the five experts. The experts show substantial agreement on many value tradeoffs, especially those concerning health and safety $\left(X_{1}\right.$ to $\left.X_{4}\right)$, jobs lost or created $\left(X_{8}\right.$ and $\left.X_{9}\right)$, acres restricted for Native American use $\left(\mathrm{X}_{10}\right)$, and technology benefits $\left(\mathrm{X}_{13}\right)$. 


\begin{tabular}{|c|c|c|c|}
\hline $\begin{array}{l}\text { 1. Unit of Ends } \\
\text { Measure }\end{array}$ & $\begin{array}{l}\text { 2. Value } \\
\text { Tradeoff }\end{array}$ & $\begin{array}{l}\text { 3. How Value Tradeoff was } \\
\text { Determined }\end{array}$ & 4. Useful Information \\
\hline $\begin{array}{l}X_{1}=\text { year of } \\
\text { worker-life lost }\end{array}$ & $\$ 100,000$ & $\begin{array}{l}1 \text { year of life lost for worker } \\
\text { equivalent to } 10 \text { years of sickness. }\end{array}$ & $\begin{array}{l}\text { What is the age of workers who } \\
\text { die? }\end{array}$ \\
\hline $\begin{array}{l}X_{2}=\text { year of } \\
\text { worker sickness } \\
\text { or serious injury }\end{array}$ & $\$ 10,000$ & $\begin{array}{l}\text { Direct assessment assuming that } \\
\text { sick workers are financially } \\
\text { compensated by insurance. }\end{array}$ & $\begin{array}{l}\text { Are sick workers compensated? } \\
\text { How and how much? }\end{array}$ \\
\hline $\begin{array}{l}\mathbf{X}_{\mathbf{3}}=\text { year of } \\
\text { public-life lost }\end{array}$ & $\$ 130,000$ & $\begin{array}{l}\text { A public life-year is weighted } 1.3 \\
\text { times a worker life-year in } X_{1} \text {. }\end{array}$ & $\begin{array}{l}\text { What is the age of people who } \\
\text { die? }\end{array}$ \\
\hline $\begin{array}{l}\mathbf{X}_{4}=\text { year of } \\
\text { public sickness or } \\
\text { serious injury }\end{array}$ & $\$ 13,000$ & $\begin{array}{l}\text { A public year of sickness is } \\
\text { weighted } 1.3 \text { times a worker year } \\
\text { of sickness in } X_{2} \text {. }\end{array}$ & $\begin{array}{l}\text { Are sick members of the public } \\
\text { compensated? How and how } \\
\text { much? }\end{array}$ \\
\hline $\begin{array}{l}\mathrm{X}_{5}=\mathrm{a} \text { discharge } \\
\text { into the Columbia } \\
\text { River that exceeds } \\
\text { clean water } \\
\text { standards }\end{array}$ & $\$ 30,000,000$ & $\begin{array}{l}\text { Direct assessment assuming there } \\
\text { are no consequences to human } \\
\text { health, but there are cpnsequences } \\
\text { to (fish, agricultural uses of water, } \\
\text { and psychiological impacts that } \\
\text { cause human effects. Checks } \\
\text { indicated this is equivilant to } 300 \\
\text { years of worker life-lost and } 600 \\
\text { acre permanently restricted } \\
\text { because of waste storage. }\end{array}$ & $\begin{array}{l}\text { A description of the } \\
\text { discharge. } \\
\text { A description of the full } \\
\text { consequences of the } \\
\text { discharge. }\end{array}$ \\
\hline $\begin{array}{l}X_{6}=\text { An acre of } \\
\text { Hanford restricted } \\
\text { because of } \\
\text { groundwater } \\
\text { contamination }\end{array}$ & $\$ 50,000$ & $\begin{array}{l}\text { Tradeoff set equal to acre value for } \\
\mathrm{X}_{7}\end{array}$ & \\
\hline $\begin{array}{l}X_{7}=\text { An acre of } \\
\text { Hanford } \\
\text { permanently } \\
\text { allocated for } \\
\text { waste disposal }\end{array}$ & $\$ 50,000$ & $\begin{array}{l}\text { Direct assessment assuming there } \\
\text { would always be at least one acre } \\
\text { for storage. Hence, this value } \\
\text { tradeoff neglected the 'existence of } \\
\text { waste' value of eliminating that } \\
\text { last acre. }\end{array}$ & $\begin{array}{l}\text { The potential uses of the land, } \\
\text { value of their uses, and the } \\
\text { number of individuals interested } \\
\text { in the uses. }\end{array}$ \\
\hline $\begin{array}{l}X_{8}=A \text { worker } \\
\text { forced to leave the } \\
\text { area }\end{array}$ & $\$ 10,000$ & $\begin{array}{l}\text { The assessment assumes that the } \\
\text { move provides an equivalent job. } \\
\text { Value tradeoff is set equal to a year } \\
\text { of worker sickness of } X_{2} \text {. }\end{array}$ & $\begin{array}{l}\text { Describe clearly the scenario that } \\
\text { is meant by a worker forced to } \\
\text { leave the area. }\end{array}$ \\
\hline
\end{tabular}


Table 5, continued

\begin{tabular}{|c|c|c|c|}
\hline $\begin{array}{l}\mathrm{X}_{9}=\text { A new (non- } \\
\text { Hanford cleanup) } \\
\text { job created }\end{array}$ & $\$ 8,000$ & $\begin{array}{l}\text { Direct assessment assuming this } \\
\text { isslioghtly less important than a } \\
\text { worker forced to leave the area in } \\
\mathrm{X}_{8} \text {. }\end{array}$ & $\begin{array}{l}\text { Be specific about the details of } \\
\text { the job created. }\end{array}$ \\
\hline $\begin{array}{l}\mathrm{X}_{10}=\text { One acre of } \\
\text { Hanford not } \\
\text { available for } \\
\text { Native American } \\
\text { use }\end{array}$ & $\$ 10,000$ & $\begin{array}{l}\text { Direct assessment assuming this is } \\
\text { an acre not available accounted for } \\
\text { in } \mathrm{X}_{6} \text { or } \mathrm{X}_{7} \text {. The value tradeoff } \\
\text { assumes this acre is of interest to } \\
\text { Native Americans, so the group of } \\
\text { individuals not able to use the acre } \\
\text { in larger than otherwise would be } \\
\text { the case. Assumes acre is not a } \\
\text { special site. The value is much less } \\
\text { than the restriction of an acre } \\
\text { because of groundwater } \\
\text { contamination, as it is on top of that } \\
\text { value. }\end{array}$ & $\begin{array}{l}\text { The Native Americans should } \\
\text { be asked these tradeoffs. } \\
\text { Information about their } \\
\text { reasoning would be useful. } \\
\text { How many areas of Hanford } \\
\text { are of interest to Native } \\
\text { Americans? Why are these of } \\
\text { interest? }\end{array}$ \\
\hline $\begin{array}{l}\mathrm{X}_{11}=\text { One } \\
\text { disturbed or } \\
\text { inaccessible } \\
\text { religious or } \\
\text { archeological site } \\
\text { important the the } \\
\text { Native Americans } \\
\end{array}$ & $\$ 100,000$ & $\begin{array}{l}\text { The value is equivalent to } 10 \text { acres } \\
\text { of } X_{10} \text {. Assessment assumed less } \\
\text { than } 10 \text { such sites exist and each is } \\
\text { at most a few acres in size. }\end{array}$ & $\begin{array}{l}\text { What are the sites? How many? } \\
\text { What size? Obtain Native } \\
\text { American value judgments on } \\
\text { this. }\end{array}$ \\
\hline $\begin{array}{l}\mathbf{X}_{12}=\text { One } \\
\text { violation of the } \\
\text { Clean Water Act }\end{array}$ & $\$ 100,000$ & $\begin{array}{l}\text { Direct assessment based on } \\
\text { importance of showing respect for } \\
\text { the law. This assumed that the } \\
\text { violation was not intended, but that } \\
\text { it would be publicly known that the } \\
\text { violation occurred. }\end{array}$ & $\begin{array}{l}\text { What is the legal liability for a } \\
\text { violation? What consequences } \\
\text { are assumed to result? Are } \\
\text { there prison terms or fines? }\end{array}$ \\
\hline $\begin{array}{l}X_{13}=\$ 1,000 \text { life- } \\
\text { cycle cost }\end{array}$ & $\$ 1,000$ & Simple reasoning & \\
\hline
\end{tabular}




\begin{tabular}{|c|c|c|c|}
\hline $\begin{array}{l}\text { 1. Unit of Ends } \\
\text { Measure }\end{array}$ & $\begin{array}{l}\text { 2. Value } \\
\text { Tradeoff }\end{array}$ & $\begin{array}{l}\text { 3. How Value Tradeoff was } \\
\text { Determined }\end{array}$ & 4. Useful Information \\
\hline $\begin{array}{l}X_{1}=\text { year of } \\
\text { worker-life lost }\end{array}$ & $\$ 40,000$ & $\begin{array}{l}\text { Started with } \$ .5 \text { to } \$ 1 \text { million per } \\
\text { worker life, with an average of } 25 \\
\text { years of remaining life } \\
\text { expectancy, used } \$ 1 \text { million }\end{array}$ & $\begin{array}{l}\text { Nature of exposure; identifiability } \\
\text { of fatality; programmatic impacts? }\end{array}$ \\
\hline $\begin{array}{l}\mathbf{X}_{2}=\text { year of } \\
\text { worker sickness } \\
\text { or serious injury }\end{array}$ & $\$ 13,000$ & $\begin{array}{l}\text { Assumes that worker is fully } \\
\text { compensated and that risks are } \\
\text { pooled; valued at } 1 / 3 \text { of a year of a } \\
\text { worker life lost. }\end{array}$ & $\begin{array}{l}\text { Seriousness of sickness, length } \\
\text { of sickness for an individual? }\end{array}$ \\
\hline $\begin{array}{l}X_{3}=\text { year of } \\
\text { public-life lost }\end{array}$ & $\$ 125,000$ & $\begin{array}{l}\text { Started with } \$ 5 \text { million/life lost for } \\
\text { member of public using a } \\
\text { multiplier of } 5 \text { on } X_{1} \text {. Also, } \\
\text { assumed } 40 \text { years of remaining life } \\
\text { expectancy in public instead of } 25 \\
\text { years for workers. }\end{array}$ & \\
\hline $\begin{array}{l}X_{4}=\text { year of } \\
\text { public sickness or } \\
\text { serious injury }\end{array}$ & $\$ 40,000$ & $\begin{array}{l}\text { A year of public sickness or } \\
\text { serious injury was valued at } 1 / 3 \text { of } \\
\text { a year of public life lost. }\end{array}$ & \\
\hline $\begin{array}{l}\mathrm{X}_{\mathbf{5}}=\text { a discharge } \\
\text { into the Columbia } \\
\text { River that exceeds } \\
\text { clean water } \\
\text { standards }\end{array}$ & $\$ 5,000,000$ & $\begin{array}{l}\text { Direct assessment assuming a } \\
\text { major discharge, but no } \\
\text { consequences to human health. } \\
\text { Further assumes that there are } \\
\text { some, if minor effects on river and } \\
\text { river uses. Could be as low as } 0 \\
\text { and as high as tens of millions, } \\
\text { depending on size of spill. }\end{array}$ & $\begin{array}{l}\text { - effect on river uses? } \\
\text { - significance of the spill? } \\
\text { bource of the spill (e.g., K } \\
\text { basin)? } \\
\text { - Programmatic impacts? }\end{array}$ \\
\hline $\begin{array}{l}\mathrm{X}_{6}=\text { An acre of } \\
\text { Hanford restricted } \\
\text { because of } \\
\text { groundwater } \\
\text { contamination } \\
\end{array}$ & $\$ 2,000$ & $\begin{array}{l}\text { Considers very long term } \\
\text { restrictions, similar to the } \\
\text { permanent allocation in } X_{7}\end{array}$ & $\begin{array}{l}\text { How long will the contamination } \\
\text { last? }\end{array}$ \\
\hline $\begin{array}{l}X_{7}=\text { An acre of } \\
\text { Hanford } \\
\text { permanently } \\
\text { allocated for } \\
\text { waste disposal }\end{array}$ & $\$ 2,000$ & $\begin{array}{l}\text { Assumes land value of about } \\
\$ 2,000 / \text { acre and that there already } \\
\text { are other areas that are } \\
\text { permanently allocated for waste } \\
\text { disposal }\end{array}$ & \\
\hline $\begin{array}{l}X_{8}=A \text { worker } \\
\text { forced to leave the } \\
\text { area }\end{array}$ & $\$ 20,000$ & $\begin{array}{l}\text { Compensation for } 6 \text { months of lost } \\
\text { wages moving expenses }\end{array}$ & $\begin{array}{l}\text { What are the ripple effects and } \\
\text { social costs of losing a worker } \\
\text { from the area? }\end{array}$ \\
\hline
\end{tabular}


Table 6 , continued

\begin{tabular}{|l|c|l|l|}
\hline $\begin{array}{l}\mathbf{X}_{\mathbf{9}}=\mathbf{A} \text { new (non- } \\
\text { Hanford cleanup) } \\
\text { job created }\end{array}$ & $\$ 20,000$ & $\begin{array}{l}\text { Assumed to be of same value as } \\
\text { avoiding to force a worker to leave } \\
\text { the area }\end{array}$ & $\cdot$ \\
\hline $\begin{array}{l}\mathbf{X}_{10}=\text { One acre of } \\
\text { Hanford not } \\
\text { available for } \\
\text { Native American } \\
\text { use }\end{array}$ & $\$ 10,000$ & $\begin{array}{l}\text { Assumes that this is an "ordinary" } \\
\text { acre of Hanford and that Native } \\
\text { American Indians are able to use this } \\
\text { land for fishing, hunting and } \\
\text { gathering. Five times an acre that is } \\
\text { of no interest to the Native American } \\
\text { Indians. }\end{array}$ & \\
\hline $\begin{array}{l}\mathbf{X}_{11}=\text { One } \\
\text { disturbed or } \\
\text { inaccessible } \\
\text { religious or } \\
\text { archeological site } \\
\text { important to the } \\
\text { Native Americans }\end{array}$ & $\$ 1,000,000$ & $\begin{array}{l}\text { Assumes a significant site that is } \\
\text { currently disturbed. Main } \\
\text { considerations were the costs of } \\
\text { remediation of this site. }\end{array}$ & How significant is the site? \\
\hline $\begin{array}{l}\mathbf{X}_{12}=\text { One } \\
\text { volation of a } \\
\text { major compliance } \\
\text { agreement or } \\
\text { regulation }\end{array}$ & $\$ 1,000,000$ & $\begin{array}{l}\text { Assumes a real compliance problem } \\
\text { with State enforcement and fines. } \\
\text { Considered mainly the equivalent } \\
\text { cost of programmatic impacts }\end{array}$ & $\begin{array}{l}\text { Is this a violation of an } \\
\text { important regulation or } \\
\text { agreement? }\end{array}$ \\
\hline $\begin{array}{l}\mathbf{X}_{13}=\text { One major } \\
\text { new technology }\end{array}$ & $\$ 50,000$ & $\begin{array}{l}\text { Should be counted as a percentage } \\
\text { of the direct benefits as "spin-off" } \\
\text { benefits }\end{array}$ & $\begin{array}{l}\text { What is the technology and } \\
\text { what is the value of its direct } \\
\text { benefits? }\end{array}$ \\
\hline $\begin{array}{l}\mathbf{X}_{14}=\$ 1,000 \text { life- } \\
\text { cycle cost }\end{array}$ & $\$ 1,000$ & \begin{tabular}{l} 
Simple reasoning \\
\hline
\end{tabular}
\end{tabular}




\section{TABLE 7: SUMMARY OF VALUE TRADEOFFS FOR UNITS OF ENDS MEASURES}

\begin{tabular}{|c|c|c|c|c|c|c|}
\hline \multirow[b]{2}{*}{ Ends Measure Unit } & \multicolumn{5}{|c|}{ Tradeoff Made by Expert } & \multirow[b]{2}{*}{$\begin{array}{c}\text { Rounded } \\
\text { Geometric Mean }\end{array}$} \\
\hline & $\mathbf{A}$ & $\mathbf{B}$ & C & $\mathbf{D}$ & $\mathbf{E}$ & \\
\hline X1: Year of worker life lost & $\$ 100,000$ & $\$ 100,000$ & $\$ 200,000$ & $\$ 100,000$ & $\$ 40 ; 000$ & $\$ 100,000$ \\
\hline X2: Year of worker sickness/injury & $\$ 10,000$ & $\$ 30,000$ & $\$ 40,000$ & $\$ 10,000$ & $\$ 13,000$ & $\$ 20,000$ \\
\hline X3: Year of public life lost & $\$ 130,000$ & $\$ 300,000$ & $\$ 500,000$ & $\$ 500,000$ & $\$ 125,000$ & $\$ 250,000$ \\
\hline X4: Year of public sickness/injury & $\$ 13,000$ & $\$ 90,000$ & $\$ 100,000$ & $\$ 50,000$ & $\$ 40,000$ & $\$ 50,000$ \\
\hline X5: Discharge into the Columbia River & $\$ 30,000,000$ & $\$ 5,000,000$ & $\$ 1,000,000$ & $\$ 3,000,000$ & $\$ 5,000,000$ & $\$ 5,000,000$ \\
\hline X6: Restricted acre - groundwater & $\$ 50,000$ & $\$ 1,000$ & $\$ 125$ & $\$ 94$ & $\$ 2,000$ & $\$ 1,000$ \\
\hline X7: Restricted acre - perm. waste disposal & $\$ 50,000$ & $\$ 20,000$ & $\$ 2,500$ & $\$ 156$ & $\$ 2,000$ & $\$ 5,000$ \\
\hline X8: A worker forced to leave the area & $\$ 10,000$ & $\$ 20,000$ & $\$ 40,000$ & $\$ 25,000$ & $\$ 20,000$ & $\$ 20,000$ \\
\hline X9: A new (non-Hanford) job created & $\$ 8,000$ & $\$ 20,000$ & $\$ 20,000$ & $\$ 100,000$ & $\$ 20,000$ & $\$ 25,000$ \\
\hline X10: Restricted acre - Native American use & $\$ 10,000$ & $\$ 2,000$ & $\$ 2,500$ & $\$ 25,000$ & $\$ 10,000$ & $\$ 5,000$ \\
\hline X11: Disturbed religious/archeological site & $\$ 100,000$ & $\$ 1,000,000$ & $\$ 5,000,000$ & $\$ 2,500,000$ & $\$ 1,000,000$ & $\$ 1,000,000$ \\
\hline X12: Major compliance violation & $\$ 100,000$ & $\$ 100,000,000$ & $\$ 15,000,000$ & $\$ 100,000$ & $\$ 1,000,000$ & $\$ 2,000,000$ \\
\hline X13: Technology with $\$ 100 \mathrm{~m}$ benefits & n.a. & $\$ 10,000,000$ & n.a. & n.a. & $\$ 5,000,000$ & $\$ 7,000,000$ \\
\hline X14: $\$ 1,000$ Life Cycle Cost & $\$ 1,000$ & $\$ 1,000$ & $\$ 1,000$ & $\$ 1,000$ & $\$ 1,000$ & $\$ 1,000$ \\
\hline
\end{tabular}


On the other measures, the experts tradeoffs show fairly large differences. First, regarding discharges in the Columbia River, the high value tradeoff by expert $A$ ( $\$ 30$ million) is 30 times higher than the low value tradeoff. This probably reflects differences in the scenarios of this discharge that the experts assumed rather than differences in values. Second, there is a fair amount of disagreement on how to value a restricted acre $\left(\mathrm{X}_{6}\right.$ and $X_{7}$ ). It appears that the experts that assigned low value tradeoffs ( $C$ and $\left.D\right)$ thought primarily of the commercial value of the land, while the experts that had high value tradeoffs thought more of intrinsic values and possibly the concerns that would be raised with these restrictions. There also are significant differences on the value tradeoff for a disturbed religious or archeological site with tradeoffs ranging from $\$ 100,000$ to $\$ 5,000,000$. These differences seems to reflect differences in the assumptions about the significance of the site rather than true value differences (recall that one expert would increase his tradeoff to $\$ 100$ million, if the site was truly significant and previously undisturbed). The large range of value tradeoffs for a compliance violation is similarly due to different assumptions about the nature of the violation.

Overall, the rounded geometric averages appear to be a very reasonable starting point for a base case value analysis. With additional work on clarifying the definitions of several performance measures and their units, it should be possible to obtain closer agreement among experts.

\section{Development of Value Tradeoffs for Performance Measures}

The general logic of calculating tradeoffs for performance measures from tradeoffs for ends measures was explained in Section 2. The specific calculations can best be explained with the example results in Table 8. In this table the value tradeoff for one unit (1000 person-rems) of the performance measure "Worker Exposure, Normal Operations" is calculated. Recall that this performance measure is related to three ends measures: 
TABLE 8: MATCHING ENDS MEASURES (EMs) AND PERFORMANCE MEASURES (PMs)

PERFORMANCE MEASURE: PERFORMANCE MEASURE UNIT (PMU):

Worker Exposure, Normal Operations 1000 Person-rems

\begin{tabular}{|c|c|c|c|c|c|}
\hline ENDS MEASURE & $\begin{array}{c}\text { EMU } \\
\text { (Ends Measure Unit) }\end{array}$ & $\begin{array}{l}\text { EMU per PMU } \\
\text { (Perf. Measure Unit) }\end{array}$ & Assumptions & $\begin{array}{l}\text { Tradeoff } \\
\text { per EMU }\end{array}$ & $\begin{array}{l}\text { Tradeoff } \\
\text { per PMU }\end{array}$ \\
\hline $\begin{array}{l}\text { Years of Worker- } \\
\text { Lives Lost }\end{array}$ & 1 Year & 30 & $\begin{array}{c}1000 \text { Rems }=1 \text { Fatality; } \\
1 \text { Fatality }=30 \text { Life-Years Lost }\end{array}$ & $\$ 100,000$ & $\$ 3,000,000$ \\
\hline $\begin{array}{l}\text { Years of Worker } \\
\text { Sickness or Injury }\end{array}$ & 1 Year & 25 & $\begin{array}{l}1000 \text { Hems = } 5 \text { Illnesses; } \\
1 \text { lliness = } 5 \text { Years of Illness }\end{array}$ & $\$ 20,000$ & $\$ 500,000$ \\
\hline Compliance & $\begin{array}{l}\text { Violation of } \\
\text { a Major TPA } \\
\text { Milestone }\end{array}$ & $5.00 \%$ & $\begin{array}{l}1 \text { exceedance of worker exposure } \\
\text { standard per 5,000 rems of exposure; } \\
1 \text { violation of worker standard = } \\
25 \% \text { severity of a TPA violation }\end{array}$ & $\$ 2,000,000$ & $\$ 100,000$ \\
\hline \multicolumn{5}{|c|}{ VALUE TRADEOFF PER PMU (1000 person-rems) } & $\$ 3,600,000$ \\
\hline
\end{tabular}


1. Years of worker lives lost

2. Years of worker sickness or injury

3. Compliance (measured in percent of a violation of a major TPA milestone)

First, implied tradeoffs for the performance measure unit (PMU $=1000$ rems) are calculated from the expressed tradeoffs for each of the three ends measure units (EMUs). For years of worker lives lost, the EMU is one year (column 2 of Table 8). Assuming that 1000 person-rems is equivalent to one statistical fatality, and that one worker fatality reduces the average life expectancy by 30 years, 1000 person-rems cause 30 lost worker years to be lost. This result is shown in column 3 of Table 8 labelled EMU per PMU. Now all one has to do is multiply the value tradeoff for the PMU $(\$ 100,000$ per lost year) by the EMU/PMU ratio (30) to obtain the equivalent value tradeoff for one PMU unit $(\$ 3,000,000)$.

A similar reasoning is applied to the second ends measure (years of worker sickness or injury) that is affected by the 1000 rems. Here we assumed that 1000 person-rems cause five cancer illnesses, and that each of these illnesses lasts five years - without leading to death. As a result, the EMU/PMU ratio is 25 , and the implied value tradeoff for 1000 rems of worker exposure is $25 * \$ 20,000=\$ 500,000$.

To illustrate a quite different reasoning process, consider the third ends measure, compliance, that is affected by the performance measure of worker exposure. The unit of the ends measure is one violation of a major TPA milestone, such as the date for completion of interim stabilization. In this case we assume that a hypothetical exposure of 5000 person-rems over the life of operations would likely involve one violation of a worker standard. We further assume that this violations would be $25 \%$ as serious as violating a major TPA milestone. Thus 1000 rems would be $5 \%$ as serious as a violation of a major TPA milestone. This result is shown in column 2 of Table 8 as the EMU/PMU ratio of $5 \%$. One violation of a major TPA milestone had a value tradeoff of 
$\$ 2,000,000$. Thus, $5 \%$ of this tradeoff $(\$ 100,000)$ is the contribution of compliance to the value tradeoff of a 1000 person-rems worker exposure.

The last step in this calculation is to add the three contributions to value tradeoff from the three ends measures. This results in an aggregate value tradeoff of $\$ 3,600,000$ per 1000 person-rems of worker exposure. Note that this addition assumes that the components contribute independently to the overall value tradeoff.

In spite of the many assumptions made in the calculation of the value tradeoff for worker exposure, the results are not dissimilar from studies of over a decade ago which postulated a tradeoff of $\$ 1000$ per person-rem (or $\$ 1$ million per 1000 rems). Adjusting the $\$ 1000$ per person-rem tradeoffs for inflation and including the compliance component would lead to very similar results to those in Table 8 .

Tables 9 and 10 show the results of the calculation of tradeoffs for the performance measures "Worker Exposure, Accidents" and "Public Exposure, Accidents". The reasoning for the EMU/PMU ratio, which is very similar to that in the previous case, is described in the fourth columns of these tables. Notice that for accidents we assume that 40 years are lost for a fatality. This is because accidents are likely to involve higher doses and lead to a development of cancer for younger adults.

Table 11 shows the results for a more complex calculation of the value tradeoff for 1000 cubic meters of high level waste. This performance measure has implications for worker and public health and safety and technology benefits. The calculations for the work health and safety implications can best be illustrated with the impacts on years of public life lost. There are two components to this. The first is through transportation accidents. The second is due to long term radiological impacts from the nuclear waste repository over thousands of years. The Environmental Impact Statement for the Tank Waste Remediation System (TWRS-EIS, Department of Energy, 1996), as well as other risk assessments of the nuclear waste repository indicate that the public radiological impacts due to 1000 cubic meters of $\mathrm{HLW}$ will be minimal. They are therefore ignored in this 
TABLE 9: MATCHING ENDS MEASURES (EMS) AND PERFORMANCE MEASURES (PMS)

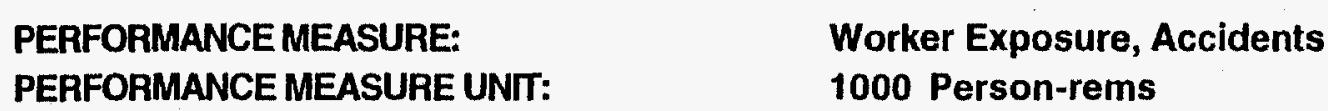

\begin{tabular}{|c|c|c|c|c|c|}
\hline ENDS MEASURE & $\begin{array}{c}\text { EMU } \\
\text { (Ends Measure Unit) }\end{array}$ & $\begin{array}{l}\text { EMU per PMU } \\
\text { (Perf. Measure Unit) }\end{array}$ & Assumptions & $\begin{array}{l}\text { Tradeoff } \\
\text { per EMU }\end{array}$ & $\begin{array}{l}\text { Tradeoff } \\
\text { per PMU }\end{array}$ \\
\hline $\begin{array}{l}\text { Years of Worker- } \\
\text { Lives Lost }\end{array}$ & 1 Year & 40 & $\begin{array}{c}1000 \text { Rems }=1 \text { Fatality; } \\
1 \text { Fatality }=40 \text { Life-Years Lost }\end{array}$ & $\$ 100,000$ & $\$ 4,000,000$ \\
\hline $\begin{array}{l}\text { Years of Worker } \\
\text { Sickness or Injury }\end{array}$ & 1 Year & 50 & $\begin{array}{l}1000 \text { Rems = } 10 \text { llinesses; } \\
1 \text { lliness = } 5 \text { Years of Iliness }\end{array}$ & $\$ 20,000$ & $\$ 1,000,000$ \\
\hline
\end{tabular}


TABLE 10: MATCHING ENDS MEASURES (EMs) AND PERFORMANCE MEASURES (PMs)

PERFORMANCEMEASURE: PERFORMANCE MEASURE UNIT:
Public Exposure, Accidents 1000 Person-rems

\begin{tabular}{|c|c|c|c|c|c|}
\hline ENDS MEASURE & $\begin{array}{c}\text { EMU } \\
\text { (Ends Measure Unit) }\end{array}$ & $\begin{array}{l}\text { EMU per PMU } \\
\text { (Pert. Measure Unit) }\end{array}$ & Assumptions & $\begin{array}{l}\text { Tradeoff } \\
\text { per EMU }\end{array}$ & $\begin{array}{l}\text { Tradeoff } \\
\text { per PMU }\end{array}$ \\
\hline $\begin{array}{l}\text { Years of Public- } \\
\text { Lives Lost }\end{array}$ & 1 Year & 40 & $\begin{array}{c}1000 \text { Rems }=1 \text { Fatality; } \\
1 \text { Fatality }=40 \text { Life-Years Lost }\end{array}$ & $\$ 250,000$ & $\$ 10,000,000$ \\
\hline $\begin{array}{l}\text { Years of Public } \\
\text { Sickness or Injury }\end{array}$ & 1 Year & 50 & $\begin{array}{l}1000 \text { Rems = } 10 \text { illnesses; } \\
1 \text { ilness = } 5 \text { Years of lilness }\end{array}$ & $\$ 50,000$ & $\$ 2,500,000$ \\
\hline Compliance & $\begin{array}{l}1 \text { Violation of } \\
\text { a Major TPA } \\
\text { Milestone }\end{array}$ & $5.00 \%$ & $\begin{array}{l}1 \text { exceedance of worker exposure } \\
\text { standard per } 5,000 \text { rems of exposure; } \\
1 \text { violation of worker standard = } \\
25 \% \text { severity of a TPA violation }\end{array}$ & $\$ 2,000,000$ & $\$ 100,000$ \\
\hline \multicolumn{5}{|c|}{ VALUETRADEOFF PER EMU (1000 Person-rems) } & $\$ 12,600,000$ \\
\hline
\end{tabular}


TABLE 11: MATCHING ENDS MEASURES (EMs) AND PERFORMANCE MEASURES (PMs)

PERFORMANCE MEASURE: PERFORMANCE MEASURE UNIT:
Amount of High-Level Waste Shipped Offsite 1000 Cubic Meters

\begin{tabular}{|c|c|c|c|c|c|}
\hline ENDS MEASURE & $\begin{array}{c}\text { EMU } \\
\text { (Ends Measure Unit) }\end{array}$ & $\begin{array}{l}\text { EMU per PMU } \\
\text { (Perf. Measure Unit) }\end{array}$ & Assumptions & $\begin{array}{l}\text { Tradeoff } \\
\text { per EMU }\end{array}$ & $\begin{array}{l}\text { Tradeoff } \\
\text { per PMU }\end{array}$ \\
\hline $\begin{array}{l}\text { Years of Worker- } \\
\text { Lives Lost }\end{array}$ & 1 Year & 5.3 & $\begin{array}{c}\text { Transporting } 15,000 \text { cubic meters }= \\
4 \text { lives lost in accidents; } 50 \% \text { workers; } \\
1 \text { fatality }=40 \text { life-years lost }\end{array}$ & $\$ 100,000$ & $\$ 533,000$ \\
\hline $\begin{array}{l}\text { Years of Worker } \\
\text { Sickness or injury }\end{array}$ & 1 Year & 13 & $\begin{array}{l}1 \text { fatality }=5 \text { serious injuries } \\
1 \text { serious injury }=10 \text { life-years lost }\end{array}$ & $\$ 20,000$ & $\$ 260,000$ \\
\hline $\begin{array}{l}\text { Years of Public } \\
\text { Lives Lost }\end{array}$ & 1 Year & 5.3 & $\begin{array}{c}\text { Transporting } 15,000 \text { cubic meters }= \\
4 \text { lives lost in accidents; } 50 \% \text { public; } \\
1 \text { fatality }=40 \text { life-years lost }\end{array}$ & $\$ 250,000$ & $\$ 1,332,500$ \\
\hline $\begin{array}{l}\text { Years of Public } \\
\text { Sickness or Injury }\end{array}$ & 1 Year & 13 & $\begin{array}{l}1 \text { tatality }=5 \text { serious injuries } \\
1 \text { serious injury }=10 \text { life-years lost }\end{array}$ & $\$ 50,000$ & $\$ 650,000$ \\
\hline
\end{tabular}


calculation. However, the TWRS-EIS estimates that there will be about 4 fatalities from transportation accidents when shipping 15,000 cubic meters of waste from the Hanford site to the repository. We assume that $50 \%$ of these fatalities are members of the public and that there is an associated 40 years lives lost per fatality. Thus we have 80 years of public lives lost, divided by 15 (to normalize for 1000 cubic meters), resulting in 5.33 years of public lives lost per 1000 cubic meters of HLW. This number is recorded as the EMU/PMU ratio in column 5.33 of Table 11 . The remaining calculation is to multiply this ratio with the value tradeoffs for one year of public lives lost $(\$ 250,000)$ resulting in a value tradeoff for 1000 cubic meters of $H L W$ of $\$ 1,332,500$.

The calculations for the ends measure "Technology Benefits" are somewhat different. First, reducing HLW goes hand in hand with new technology for separating the HLW component of the Hanford tank wastes. Thus the lower the HLW component, the more improved the technology is. This improvement would primarily pay off as a direct cost savings for treating and disposing the $\mathrm{HLW}$. According to the value experts, about $7.0 \%$ of that direct benefit should be counted as technology transfer and spin off benefits. Using figures from the TWRS-EIS, we estimate that the cost of treatment and disposal of 1000 cubic meters of HLW is about $\$ 500$ million. Assuming further that this expense is worth the benefits, we assign a direct benefit to eliminating 1000 cubic meters of HLW of $\$ 500$ million. Since this is five times the benefit of the unit definition of the technology innovation benefit measure, the EMU/PMU ratio is 5. Multiplying this ratio with the $\$ 7$ million value tradeoff for the ends measure unit, we obtain a value tradeoff of $\$ 35$ million for 1000 cubic meters of $\mathrm{HLW}$.

Similar reasoning is applied to the remaining Tables $12-15$. Clearly some assumptions in these calculations are more easy to defend than others. For example the translations from rems to fatalities and illnesses is fairly straightforward. On the other hand, there are many critical assumptions that need to be examined more closely. For example, one assumption in Table 12 was that 1000 cubic meters of low level waste disposed of at the Hanford site lead to a very small ( 0.001$)$ chance of causing an exceedance of a clean water standard over the life-time of the disposal. This assumption was made primarily for 
TABLE 12: MATCHING ENDS MEASURES (EMs) AND PERFORMANCE MEASURES (PMS)

PERFORMANCEMEASURE: PERFORMANCE MEASURE UNT:
Low Level Waste Left on Site

1000 cubic meters of LLW in glass (including $48 \mathrm{Ci} /$ cubic meter)

\begin{tabular}{|c|c|c|c|c|c|}
\hline ENDS MEASURE & $\begin{array}{c}\text { EMU } \\
\text { (Ends Measure Unit) }\end{array}$ & $\begin{array}{l}\text { EMU per PMU } \\
\text { (Perf. Measure Unit) }\end{array}$ & Assumptions & $\begin{array}{l}\text { Equiv. } \$ \\
\text { per EMU }\end{array}$ & $\begin{array}{l}\text { Equiv. \$ } \\
\text { per PMU }\end{array}$ \\
\hline $\begin{array}{l}\text { Exceedance of } \\
\text { Clean Water Standard }\end{array}$ & 1 Exceedance & 0.001 & $\begin{array}{l}\text { Very small chance of exceeding } \\
\text { standard with } 1000 \mathrm{MT} \text { of glass }\end{array}$ & $\$ 5,000,000$ & $\$ 5,000$ \\
\hline $\begin{array}{l}\text { Area Restricted for } \\
\text { Groundwater Use. }\end{array}$ & 1 Acre & 100 & $\begin{array}{l}1 \text { acre to dispose } 1000 \mathrm{MT}=100 \text { acres } \\
\text { of restricted groundwater use }\end{array}$ & $\$ 1,000$ & $\$ 100,000$ \\
\hline $\begin{array}{l}\text { Area Restricted for } \\
\text { Native American Use }\end{array}$ & 1 Acre & 100 & $\begin{array}{c}\text { About the same area as restricted for } \\
\text { ground water use }\end{array}$ & $\$ 5,000$ & $\$ 500,000$ \\
\hline $\begin{array}{l}\text { Disturbed Religious or } \\
\text { Archeological Sites }\end{array}$ & 1 Site & 0.01 & $\begin{array}{l}10 \% \text { chance that an acre used for waste } \\
\text { disposal would include such site }\end{array}$ & $\$ 1,000,000$ & $\$ 10,000$ \\
\hline \multicolumn{5}{|c|}{ VALUE TRADEOFF PEA PMU (1000 metric tons of LLW) } & $\$ 7,620,000$ \\
\hline
\end{tabular}


TABLE 13: MATCHING ENDS MEASURES (EMs) AND PERFORMANCE MEASURES (PMs)

PERFORMANCE MEASURE: PERFORMANCE MEASURE UNIT:

VALUE TRADEOFF PER PMU (Years to Interim Stabilization)

\begin{tabular}{|l|c|c|c|c|c|}
\hline ENDS MEASURE & $\begin{array}{c}\text { EMU } \\
\text { (Ends Measure Unil) }\end{array}$ & $\begin{array}{c}\text { EMU per PMU } \\
\text { (Pert. Measure Unit) }\end{array}$ & $\begin{array}{c}\text { Assumptions } \\
\text { per EMU }\end{array}$ & $\begin{array}{c}\text { Tradeoff } \\
\text { per PMU }\end{array}$ \\
\hline Compliance & $\begin{array}{c}1 \text { Violation of } \\
\text { a Major TPA } \\
\text { Milestone }\end{array}$ & $\begin{array}{c}0 \text { for < 3years } \\
50 \text { for each add. yr. }\end{array}$ & $\begin{array}{c}\text { TPA interim stabilization milestone is } 1999, \\
\text { exceeding it by two years is a major violation }\end{array}$ & $\begin{array}{c}\$ 2,000,000 \\
\$ 0 ~ i f<3 \text { years, } \\
12.5 \text { million/yr. } \\
\text { otherwise }\end{array}$ \\
\hline
\end{tabular}

Time to Interim Stabilization

Years 
TABLE 14: MATCHING ENDS MEASURES (EMs) AND PERFORMANCE MEASURES (PMs)

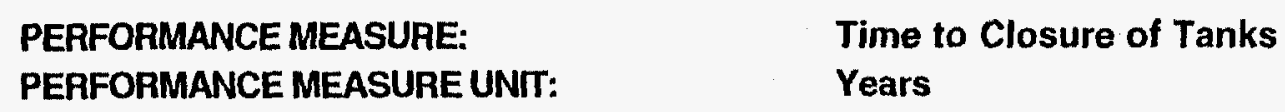

\begin{tabular}{|c|c|c|c|c|c|}
\hline Compliance & $\begin{array}{l}1 \text { Violation of } \\
\text { a Major TPA } \\
\text { Milestone }\end{array}$ & $\begin{array}{c}0 \text { for }<24 \text { years } \\
.20 \text { for each add. } y r \text {. }\end{array}$ & $\begin{array}{l}\text { TPA closure milestone is } 2020 \\
\text { exceeding it by } 5 \text { yrs. is a major violation }\end{array}$ & $\$ 2,000,000$ & $\begin{array}{c}\$ 0 \text { if }<24 \text { years, } \\
\$ 5 / y r . \text { million } \\
\text { otherwise }\end{array}$ \\
\hline \multicolumn{4}{|c|}{ VALUE TRADEOFF PER PMU (YEARS (Years until Tank Closure) } & $\begin{array}{l}\text { if }<24 \text { years } \\
\text { otherwise }\end{array}$ & $\begin{array}{c}\$ 0 \\
\$ 400,000\end{array}$ \\
\hline
\end{tabular}


TABLE 15: MATCHING ENDS MEASURES (EMS) AND PERFORMANCE MEASURES (PMS)

PERFORMANCE MEASURE: PERFORMANCE MEASURE UNT:

\begin{tabular}{|c|c|c|c|c|c|}
\hline ENDS MEASURE & $\begin{array}{c}\text { EMU } \\
\text { (Ends Measure Unit) }\end{array}$ & $\begin{array}{l}\text { EMU per PMU } \\
\text { (Perf. Measure Unit) }\end{array}$ & Assumptions & $\begin{array}{l}\text { Equiv. \$ } \\
\text { per EMU }\end{array}$ & $\begin{array}{l}\text { Equiv. \$ } \\
\text { per PMU }\end{array}$ \\
\hline Total Life Cycle Cost & $\$ 1$ million & 1 & Dollar for dollar & $\$ 1,000,000$ & $\$ 1,000,000$ \\
\hline $\begin{array}{l}\text { Workers Forced } \\
\text { to Leave the Area }\end{array}$ & 1 Worker & -5 & Loss of $\$ 1$ million $=$ loss of 5 jobs & $\$ 20,000$ & $(\$ 100,000)$ \\
\hline $\begin{array}{l}\text { New Jobs Created } \\
\text { (Non-Hanford) or Lost }\end{array}$ & $1 \mathrm{Jab}$ & -10 & $\begin{array}{l}\text { For each Hanford job gained or lost, } \\
\text { two other jobs are created or lost }\end{array}$ & $\$ 25,000$ & $(\$ 250,000)$ \\
\hline \multicolumn{5}{|c|}{ DOLLAR TRADEOFF PER PMU (\$1 Million) } & $\$ 650,000$ \\
\hline
\end{tabular}

Total Life Cycle Cost

$\$ 1$ million 
illustrative purposes and will need to be checked very carefully. The point of this report is not to defend every assumption and calculation in detail, but to provide an illustration of the overall approach and a starting point for further refinement.

The results of the calculations of the value tradeoffs for the performance measures are summarized in Table 16. Overall, one should have more confidence in the value tradeoffs for the ends measures (Table 7), since they were obtained directly, without making many assumptions about the relationships between performance and ends measures. Thus, we suggest that the results in Table 16 be considered as very preliminary.

\section{Uses and Limitations of the Value Tradeoffs}

The TWRS program has developed a systematic approach to making decisions that involves the following steps (see Robershotte et al., 1995):

1) Define the frame of the decision

2) State issues

3) Develop a set of alternatives

4) Formulate decision values

5) Translate decision values into a set of measures

6) Evaluate alternatives

7) Present the results to the decision body

Previous reports (Armacost et al., 1995; Keeney and von Winterfeldt, 1996) have developed values, objectives and measures to assist decision makers and specialists in steps 4 and 5 . This report is to provide help in step 6 . Step 6 consists of two very distinct parts. The first is the (factual) estimation of how the alternatives perform on the measures of objectives. The results of these estimations are typically summarized in an alternatives by objectives matrix. The cells in this matrix describe, in terms of the measures, how well an alternative achieves each of the objectives. 
TABLE 16: SUMMARY OF TRADEOFFS FOR PERFORMANCE MEASURE UNITS

\begin{tabular}{|l|c|c|c|}
\hline Performance Measure & Unit & $\begin{array}{c}\text { Dollar } \\
\text { Tradeoff }\end{array}$ & $\begin{array}{c}\text { Normalized } \\
\text { Weight per Unit }\end{array}$ \\
\hline Worker Exposure, Normal Operations & 1,000 person-rems & $\$ 3,600,000$ & $5.24 \%$ \\
Worker Exposure, Accidents & 1,000 person-rems & $\$ 5,100,000$ & $5.29 \%$ \\
Public Exposure, Accidents & 1,000 person-rems & $\$ 12,600,000$ & $13.06 \%$ \\
Amount of HLW Shipped Off-Site & 1,000 cubic meters & $\$ 37,775,500$ & $39.15 \%$ \\
Time to Interim Stabilization & Years & $\$ 1,000,000$ & $1.04 \%$ \\
Time to Closure of Tanks & Years & $\$ 400,000$ & $0.41 \%$ \\
Low Level Waste Left on Site & 1,000 cubic meters & $\$ 7,620,000$ & $7.90 \%$ \\
Total Life-Cycle Cost & $\$ 1$ million & $\$ 650,000$ & $0.67 \%$ \\
\hline
\end{tabular}


Often this summary is sufficient for decision making, for example, when it becomes clear that one alternative is best on all or almost all measures. Sometimes the implications are not so clear and difficult tradeoffs need to be made. In that case, it is useful to develop a formal evaluation model that aggregates the information about alternatives across objectives. All value models that aggregate across objectives require the use of value tradeoffs. In the past, these value tradeoffs were elicited from decision makers and, in some cases, from stakeholders, separately for each decision problem.

This report began the development of a set of tradeoffs that can consistently be applied to a variety of TWRS decisions. The report provides two sets of tradeoffs: For units of ends measures (Table 7) and for units of performance measures (Table 16). These tradeoffs should be considered preliminary, subject to further elicitations and analysis. However, they provide a starting point for building a value model and to conduct sensitivity analyses with it.

To use the tradeoffs, the analyst who supports the decision maker has to first decide whether to work with the set of ends measures or with the set of performance measures to evaluate alternatives. In most cases, this choice will depend on the available information and the resource constraints of the analysis. With less information and less resources, using performance measures is the more practical and economic choice.

The analyst then has to assemble the information about the alternatives in the form of an alternatives by objectives matrix. Making the simplifying assumption that all measures are linearly related to the overall decision value, an alternative $A_{j}$ can then be evaluated by

$$
C\left(A_{j}\right)=\Sigma w_{i}^{*} c_{i}\left(A_{j}\right)
$$

where $C\left(A_{j}\right)$ is the overall equivalent cost (negative value) of alternative $A_{j}, w_{i}$ is the tradeoff for one unit of the $i$-th measure from either Table 7 or Table 16 , and $c_{i}\left(A_{j}\right)$ is the 
estimate of $A_{j}$ expressed in units of the $i$-th measure. Subsequently, the alternatives are rank ordered in terms of overall equivalent cost, with the alternative having the lowest equivalent cost being best.

While the tradeoffs in Tables 7 and 16 are a starting point for this evaluation, several caveats need to be stated combined with suggestions for improvements. Regarding tradeoffs for ends measures:

Caveat: These tradeoffs were based on the judgments of five experts who have thought deeply about value issues, risk issues, and environmental issues. Yet, they do not necessarily represent all experts in this area and they certainly do not represent all the groups that may have an interest or stake in the implications of decisions about Hanford.

Recommendation: A broader range of experts should be involved in eliciting value tradeoffs as well as groups of non-experts. The experts themselves stated that on some issues they felt that others (e.g. Native Americans) were better judges of the value tradeoffs.

Caveat: The experts in the tradeoff elicitation often stated that they needed more information to make an informed judgment. In some cases assumptions were made to substitute for this information. The tradeoffs that we obtained are only as valid as these assumptions.

Recommendation: The measures and their units should be more clearly defined to provide a common base for making tradeoffs. Also information about the severity of some of the consequences (for example of a toxic spill into the Columbia River) should be described to assist in the tradeoff assessment.

Caveat: In some cases the experts' value tradeoffs are different because they used different assumptions and definitions. 
Recommendation: A common set of definitions and assumptions should be developed to assist the tradeoff assessment.

Regarding tradeoffs for performance measures, the following caveats and recommendations are important:

Caveat: The calculations of tradeoffs for performance measures used many strong assumptions about the relationships between a performance measure and an ends measure and the results are only as valid as these assumptions.

Recommendation: These assumptions should be checked, using existing models and knowledge about the relationships between performance and ends measures. The assumptions about the relationships should be revised as appropriate.

Caveat: The calculation of tradeoffs for performance measures assumed that the overall tradeoff for a unit in a performance measure is additive across ends measures. This may not necessarily be true.

Recommendation: The additivity assumptions needs to be checked carefully with existing models and data that relate performance measures to ends measures. Revisions should be made where appropriate.

Caveat: The calculations of tradeoffs for performance measures was not independently checked against some other method for assessing tradeoffs on performance measures.

Recommendation: It would be desirable to assess tradeoffs on performance measures directly from experts and to compare and reconcile the results with the calculated ones. 


\section{References}

Armacost, L.L., von Winterfeldt, D., Creighton, J., and Robershotte, M.A. (1994). Public Values Related to Decisions in the Tank Waste Remediation System Program. Technical Report No. PNL-10107/UC-630. Battelle Pacific Northwest Laboratory: Richland, WA.

Department of Energy. (1996) Tank Waste Remediation System, Hanford Site, Richland, Washington, Final Environmental Impact Statement. U.S. Department of Energy: Washington; D.C.

Keeney, R.L. and von Winterfeldt, D. (1996). Value-Based Performance Measures for Hanford Tank Waste Remediation System (TWRS) Program. Technical Report No. PNNL-10946/UC-630. Battelle Pacific Northwest National Laboratory: Richland, WA.

Robershotte, M.A., Dirks, L.L., Seaver, D.A., Brothers, A.J., and Madden. M.S. (1995). Tank-Waste Remediation System Decision Guide. Technical Report No. PNL10589/UC-630, Battelle Pacific Northwest Laboratory: Richland, WA. 
PNNL-11724

UC-630

\section{DISTRIBUTION}

No. Of

Copies

Offsite

2. DOE Office of Scientific

and Technical Information

\section{Onsite}

5 Lockheed Martin Hanford Company

B. D. Zimmerman H6-35

L. G. Peck H6-35

J. S. Garfield H5-49

E. A. Fredenburg H6-12

M. L. Grygiel . H8-71

16 Pacific Northwest National Laboratory

D. A. Seaver K8-07 (10)

M. S. Madden K8-07

A. J. Brothers K8-07

A. L. Franklin K8-07

P. M. Daling K8-07

M. J. Quadrel K9-70

W. A. Hesser K6-51

1 Fluor Daniel Hanford

T. G. Halverson H8-71

7 Decision Insights, Inc.

Detlof von Winterfeldt (5)

Ralph Keeney

Thomas Eppel 